\title{
INTO THE WOODS: BROADCASTERS, BUREAUCRATS, AND CHILDREN'S TELEVISION PROGRAMMING
}

\author{
RONALD J. KROTOSZYNSKI, JR. ${ }^{\dagger}$ \\ Into the woods and down the dell, \\ In vain, perhaps, but who can tell ${ }^{1}$
}

\section{INTRODUCTION}

In 1961, Federal Communications Commission Chairman Newton Minow decried the "vast wasteland" of commercial television, including the paucity of educational children's programming, and challenged commercial television broadcasters to do a better job. ${ }^{2}$ Today, sonie thirty-five years later, we have before us another Chairman, Reed E. Hundt. Like Chairman Minow, Chairman Hundt appears to beheve that commercial television broadcasters can and should do more to enlighten and educate their audiences. In particular, Chairman Hundt thinks that the needs of the nation's youngest viewers are going unmet on commercial television stations.

Chairman Hundt contends that broadcasting in the public interest requires commercial television broadcasters to respect the programming needs-and limitations-of their youngest viewers. ${ }^{3}$ Specifically, the Chairman argues that to neet the needs of chil-

$\dagger$ Assistant Professor of Law, Indiana University-Indianapolis. J.D., LL.M., Duke University. I gratefully acknowledge the comments, snggestions, and contributions of former Clairman Newton N. Minow, Professors Lucas A. Powe, Jr., Rodney A. Smolla, and Cass R. Sunstein. Thanks also to Nancy M. Olson, S. Elizabeth Wilborn, Randall D. Lehner, Mary N. Newcomer, David V. Snyder, and Marilyn Mohrman-Gillis for their invaluable assistance. As always, any and all errors and omissions are my own.

1. STEPHEN SONDHEIM, Ever After, in INTO THE WOODS 10 (1987) (Cast Recording Lyrics Booklet).

2. See Newton N. Minow \& Craig L. Lamay, Abandoned in the WasteLAND: ChILdREN, Television, AND the First AmENDMENT 3-7, 185, 188, 190 (1995); Minow Observes a "Vast Wasteland," BroadCASTing MAGAZINE, May 15, 1961, at 58-60 (publishing condensed version of Chairman Minow's speech).

3. Reed E. Hundt, The Public's Airwaves: What Does the Public Interest Require of Television Broadcasters?, 45 DUKE L.J. 1089 (1996). 
dren the government unust regulate violent and indecent programming. ${ }^{4} \mathrm{He}$ also asserts that the Federal Communications Commission (the Commission) has a legal and a moral obligation to ensure that commercial television broadcasters air at least a minimal amount of educational children's programming. ${ }^{5}$ To advance these goals and obhigations, the Chairman has presented three specific regulatory proposals. Two of these proposals merit only brief discussion, principally because the legal and pohicy issues surrounding thein are fairly unambiguous.

Chairman Hundt's support for recently enacted legislation mandating the inclusion of the so-called "violence chip," or "Vchip," in all television receivers does not appear to raise serious First Amendment objections. Provided that the Cominission does not impose any special burdens or restrictions on the broadcast of programming coded as "violent"-and currently no indication exists that either the Commission or Congress harbors any such intentions-this technology is the functional equivalent of a inute button. ${ }^{6}$

Chairman Hundt's observations and suggestions regarding indecent programming also do not require particularly laborious study or evaluation. Simply put, they represent an endorsenent of rather overt forms of censorship, and should be rejected out of hand both by the academy and the federal courts. ${ }^{7}$

4. Id. at 1096 .

5. Id.

6. Of course, issues of identifying and labelling "violent" programming will remain. But these issues should be little different from those associated with the operation of the Motion Picture Association of America's ratings system, or with the music mdustry's project of identifying and labelling products that feature "explicit" lyrics. Neither of these practices, by itself, raises serious First Amendment questions regarding governmental ceusorship. If the government itself attempted to label television programming, the First Amendment analysis would obvionsly be more difficult. $C f$. Telecommunications Act of 1996, Pub. L. No. 104-104, §551, 110 Stat. 56, 139-42 (providing that the Commission shall establish guidelines for the rating of programs, and explicitly prohibiting rating based on political or religious content). Moreover, it now appears that the broadcasting indnstry is committed to implementing the V-chip teclnologies voluntarily. See Christopher Stern, Coming Soon: TV Ratings, BROADCASTING \& CABLE, Feb. 19, 1996, at 6, 8.

7. But see Action for Children's Television v. FCC, 59 F.3d 1249 (D.C. Cir. 1995) (en banc), cert. denied, 116 S. Ct. 701 (1996); Action for Children's Television v. FCC (ACT IIn), 58 F.3d 654 (D.C. Cir. 1995) (en banc). The Commission could easily approach "indecent" television programming in a fashion consistent with Clairman Hundt's proposed treatinent of "violent" programming; such an approach would largely avoid the First Amendment difficulties associated with the Commission's current prograin of naked censorship. See J.M. Balkin, Media Filters, the V-Chip, and the Foundations of Broadcast 
Academic criticism of the Commission's efforts to serve as a national censor ${ }^{8}$ has been both consistent and harsh; ${ }^{9}$ no useful purpose would be served by revisiting these materials in great detail here. ${ }^{10}$ Contrary to the Chairman's suggestions, ${ }^{11}$ we do not need a government agency to protect us from ourselves by bowdlerizing the nation's television programming. ${ }^{12}$ If television or radio programming offends the sensibilities of a particular counmunity or the nation as a whole, the citizenry is more than capable of taking corrective action without the active "assistance" of the federal government. ${ }^{13}$

Chairman Hundt's third proposal, estabhishing quantitative and quahtative standards for children's educational programming, merits closer attention. Unlike the proposals regarding violence and $\mathrm{m}$ decency, the Chairman's observations about the paucity of children's educational programming raise an issue of considerable coinplexity. ${ }^{14}$

Regulation, 45 DUKE L.J. 1131 (1996).

8. Cf. 47 U.S.C. \$ 326 (1988) (stating that no provision of the Communications Act should be construed to give the Commission censorship power).

9. See, e.g., Thomas G. Krattenmaker \& LuCAS A. Powe, JR., Regulating BRoadCASt PRogramming 36-45, 229-36, 324-31 (1994); LUCAS A. POWE, JR., AMERICAN BROADCASTING AND THE FIRST AMENDMENT 162-90 (1987); $c f$. CASS R. SUNSTEIN, DEMOCRACY AND THE PROBLEM OF FREE SPEECH 17-23, 54-77, 119, 244-45 (1993) (suggesting many reasons why competition will not solve problems of broadcast speech).

10. There are two basic objections. First, the Commission's attempts to regulate indecent and obscene speech invariably squelch the airing of provocative, but artistically, philosophically, or politically serions works. See In re Pacifica Found., Inc., 2 F.C.C.R. 2698, 2698-2700 (1987); see also Board of Educ. v. Pico, 457 U.S. 853, 896-903 (1982) (Powell, J., dissenting) (providing an amnsing appendix that appears to judge a literary work on the basis of the number of four-letter words it happens to contain). Second, the project of censorship is itself hopelessly subjective, and enshrines the censors' cultural values into law, notwithstanding differing opinions within the community about the merits of a particular work. See POWE, supra note 9, at 190. As Instice Scalia lias observed, "De gustibns non est disputandun," Pope v. Illinois, 481 U.S. 497, 505 (1987) (Scalia, J., concurring), which means, roughly, "in matters of taste, there is no disputing." See also Cohen v. California, 403 U.S. 15, 25 (1971) ("[O]ne man's vulgarity is another's lyric.").

11. See Hundt, supra note 3 , at 1096.

12. See infra notes $178-82$ and accompanying text.

13. See KRATTENMAKer \& POWE, supra note 9, at 245-46, 278-80; Network Programming Chiefs Face Viewers for Quality TV, BROADCASTING, Oct. 2, 1989, at 49. Indeed, the Chairman's obsession with indecent programming appears to be an odd attempt to establish that Democrats, like many Republicans (e.g., Bob Dole and Rush Limbaugh), favor government censorship of materials that politicians deem unfit for public consunption.

14. See Hundt, supra note 3, at 1110-17. 
On one hand, as a society we have an obhgation to ensure that the educational needs of our children do not go unmet. The notion of the government commanding broadcasters to air certain kinds of programming, however, strongly cuts against the grain of the constitutional guarantee of freedom of expression. Because of the importance of the Chairman's children's programming initiative, and the difficulty of the legal and policy issues associated with it, the remainder of this Comment will focus on this issue.

\section{The Journey Begins: Chairman HundT's Proposals to ESTABLISH STANDARDS FOR CHILDREN'S EDUCATIONAL PRO- GRAMMING 。}

At the outset, it seems worthwhile to identify some common ground. No one disagrees that children should enjoy reasonable access to educational programming. Furthermore, no one seriously argues that broadcasters liave an absolute First Amendment right to air, or not to air, the programming they think best or most profitable. ${ }^{15}$ Most would also agree that ensuring the national availability of high-quality educational children's television programming through free, over-the-air television broadcasting service is a critically important public policy objective. ${ }^{16}$

Research has established that commercial broadcasters are showing little, if any, educational children's programming. ${ }^{17}$ Indeed, much of what appears on late afternoon television-when

15. For example, should the Fox network decide that a regular dose of soft-core pornography would generate the highest rents, it would not necessarily be free to implement this decision, regardless of the strength of its First Amendment claim. See, e.g., Barnes v. Glen Theatre, Inc., 501 U.S. 560 (1991) (upholding government restrictions on expressive speech, where the "speech" at issue consisted of nude dancing); New York v. Ferber, 458 U.S. 747 (1982) (holding that child pornography is not protected by the First Amendment).

16. See generally Owen M. Fiss, Why the State?, 100 HARV. L. REV. 781, 787 (1987) ("The state, like any other institution, can act either as a friend or enemy of speech and, without falling back on the libertarian presumption, we must learn to recognize when it is acting in one capacity rather than another.").

17. See Comments of Dr. Dale Kunkel, In re Policies and Rules Concerning Children's Television Programming, MM Docket No. 93-48 (FCC Oct. 16, 1995); Dale Kunkel \& Ursula Goette, Broadcasters Response to the Children's Television Act, In re Policies and Rules Concerning Children's Television Programming, MM Docket No, 93-48 (FCC Oct. 12, 1994); Dale Kunkel, Broadcaster's License Renewal Claims Regarding Children's Educational Programming, In re Policies and Rules Concerning Children's Television Programming, MM Docket No. 93-48 (FCC May 7, 1993) [hereinafter Broadcaster's License]. 
most children are watching-is hardly suitable fare.$^{18}$ Describing the problem is relatively simple; proposing a viable solution is quite another matter.

Chairman Hundt has advocated the adoption of new regulations that would clarify commercial television broadcasters' obligations to serve the educational programming needs of the nation's children. Given the importance of the stakes, the Chairman's proposals seein quite modest-indeed, almost embarrassingly so. Under the scheme set forth in the Commission's Pending Notice of Proposed Rulemaking (NPRM) ${ }^{19}$ and endorsed by Chairman Hundt, the Commission would require broadcasters to air as little as three hours per week of "core" educational children's programming. ${ }^{20}$ To avoid shirking by the broadcasters, the Commission also proposes establishing some minimal standards for defining "educational" programming, ${ }^{21}$ and may require that the programming air during time periods when significant numbers of children actually watch television. ${ }^{22}$

According to formal submissions by the National Association of Broadcasters, most stations are already meetmg both the quantitative and qualitative standards proposed in the NPRM. ${ }^{23}$ Howev-

18. MINOW \& LAMAY, supra note 2, at 36-40 (listing prograin topics for afternoon talk shows ranging froin "parents who run an escort service and their kids who help out" to "Amy Fisher's alleged jailhouse lesbian lover").

19. In re Policies and Rules Concerning Children's Television Programming, 10 F.C.C.R. 6308 (1995) [hereinafter Ongoing Children's TV Proceedings].

20. Id. at 6311-12, 6327-31, 6337-39. "Core" educational programming may have entertainment value, but a "significant" purpose of the programming must be educational. Id. at 6328.

21. Specifically, the Commission would require educational children's programming to meet six standards: (1) such programming must be specifically designed to meet the educational and informational needs of children under age 16; (2) a significant educational purpose must be identified in a written programming report to be filed with the Commission at license renewal time; (3) the programming unust air between the hours of 6 a.m. and 11 p.m.; (4) it must be regularly scheduled; (5) it must be of substautial length; and (6) it must be identified at the time it airs and elsewhere as "educational" programming. See id. at 6327-31.

The need for such standards arises from the coinmercial broadcasters' current practice of counting programs like "G.I. Joe," "Yogi Bear," and "Muppet Babies" as "educational." See Comments of Dr. Dale Kunkel, supra note 17, at 1-3; Broadcaster's License, supra note 17 , at $1-4$.

22. Ongoing Children's TV Proceedings, supra note 19, at 6329-30. These proposals are not really new. The Commission considered-and rejected-remarkably similar proposals in 1978 and 1979. See In re Children's Programming and Advertising Practices, 68 F.C.C.2d 1344, 1349-52 (1978).

23. In formal comments filed in response to the Commission's mitial Notice of Inqui- 
er, as the Chairman is well aware, the response of the broadcasting community to the proposed standards has been less than enthusiastic. ${ }^{24}$ Moreover, two of the Chairman's colleagues have raised First Amendinent objections to the adoption of such standards, ${ }^{25}$ and a third Commissioner has indicated that she is sympathetic to their point of view. ${ }^{26}$

As a practical matter, any reform proposal must enjoy the support of a nuajority of the five Commissioners. ${ }^{27}$ Accordingly,

ry, the NAB asserted that each of the four major networks show an average of 3.6 hours per week of educational children's programming. See Comments of the NAB, In re Policies and Rules Concerning Children's Television Programming, MM Docket No. 93-48, at 4, attachment 1 (FCC Oct. 16, 1995); see also Reply Comments of the NAB, In re Policies and Rules Concerning Children's Television Programming, MM Docket No. 93-48, at 5-8 (FCC June 7, 1993); Reply Comments of Dr. Dale Kunkel, In re Policies and Rules Concerning Children's Television Programming, MM Docket No. 93-48, at 2-5 (FCC June 7, 1993). More recently, the broadcasting industry clained that most commercial television stations are showing in excess of four hours of children's educational programming. See Comments of the NAB, supra, at 6. By way of contrast, public television stations air an average of thirty-five hours per week of educational children's programming. See Comments of the United Church of Christ, In re Policies and Rules Concernmg Children's Television Programming, MM Docket No. 93-48, at 4 (FCC Oct. 16, 1995).

24. See Reply Comments of the NAB, In re Policies and Rules Concerning Children's Television Programming, MM Docket No. 93-48 (FCC Nov. 20, 1995); Comments of the $\mathrm{NAB}$, In re Policies and Rules Concerning Children's Television Programming, MM Docket No. 93-48 (FCC May 7, 1993); see also Comments of Capital Cities/ABC, In re Policies and Rules Concerning Children's Television Programming, MM Docket No. 93-48 (FCC Oct. 16, 1995); Comments of CBS, In re Policies and Rules Concerning Children's Television Programming, MM Docket No. 93-48 (FCC Oct. 16, 1995); Comments of NBC, In re Policies and Rules Concerning Children's Television Programming, MM Docket No. 93-48 (FCC Oct. 16, 1995).

25. See Ongoing Children's TV Proceedings, supra note 19, at 6359-60 (separate statement of Commissioner James H. Quello); id. at 6362-65 (concurrence/dissent of Commissioner Andrew C. Barrett); see also Commissioner James H. Quello, Enough Already, Remarks Before the NAB's Children's Television Symposium 3-4 (Sept. 21, 1995) (transcript on file with author) ("In my opinion, any governinentally-imposed quantitative program requirements would constitute unnecessary, objectionable government intrusion and would never pass a First Amendinent court challenge."); cf. Robert $M$. Entman, Putting the First Amendment in its Place: Enhancing American Democracy through the Press, 1993 U. CHI. LEGAL F. 61, 73-74 (arguing that the Commission has "used the First Amendment narrowly and simplistically" when considering its impact on public policy choices).

26. See Commissioner Rachelle Clrong, Remarks to Women in Cable and Telecommunications 8 (Oct. 30, 1995) (transcript on file with author) ("I am troubled by the notion that public interest obligations of our broadcasters should be quantified."); Edmund L. Andrews, A Bitter Feud Fouls Lines at the FCC, N.Y. TIMES, Nov. 20, 1995, at D1.

27. As currently constituted, the Commission consists of five members, one of whom the President designates to serve as Chairman. See 47 U.S.C. $\$ 154$ (a) (1988). Thus, when all five Commissioners participate in a proceeding, the support of three commissioners is necessary for the Commission to act. See WIBC, Inc. v. FCC, 259 F.2d 941, 942 (D.C. 
given the publicly-stated objections of three of the five Commissioners, Chairman Hundt seems to face an uphill battle. Furthermore, even if he ultimately is able to convince one of his three skeptical colleagues to support the adoption of quantitative and qualitative standards for children's educational programming, ${ }^{28}$ some element of the commercial broadcasting community will likely attack the legality of the new regulations in federal court. ${ }^{29}$

Moving beyond political considerations, any regulatory initiative designed to increase the amount or quality of children's programming must meet two basic criteria: It must be legal (i.e., constitutional and consistent with the Commission's organic statutes), and it must be effective. I will leave to Chairman Hundt the task of mustering the political arguments needed to garner the necessary three votes,$^{30}$ and will focus instead on the legal and policy questions that his children's programming initiative raises.

The first question to be resolved is the basic legality of the proposal. Altlough reasonable minds might differ, I believe that the Commission's proposed children's programming rules do not violate the First Amendment riglits of broadcasters. ${ }^{31}$ I reach this conclusion even though I firmly believe that broadcasters slould

Cir. 1958).

28. Of course, the Children's Television Act of 1990 (CTA) presupposes that the Commission will monitor broadcasters' conpliance with the Act. 47 U.S.C. $\S 303 \mathrm{~b}$ (1988) (authorizing the Commission to prescribe the nature of service each station will offer). As a practical matter, the Commission must maintain sone sort of internal processimg guideline for establishing conpliance with the Act. See Hundt, supra note 3, at 1112. Thus, Commissioners Quello and Barrett's objections to "qualitative" standards are grossly overstated. The real question is not whether to maintain a qualitative standard; it is whether the Commission's standard should be a matter of public record. See id.

29. See, e.g., Comments of NBC, supra note 24 (setting out NBC's reasons for opposing the imposition of quantitative requirements); Chris McComell, Hundt Pitches Kids Standards, BROADCASTING \& CABLE, Jan. 29, 1996, at 18, 22 (describing unfavorable reactions from the broadcasting community to Chairman Hundt's proposal).

30. It has been said that "politics is the art of the possible." This maxim lolds true not only of legislative bodies, like the Congress, but also applies to administrative agencies that must balance the interests of conipeting interest groups, which hold diverse-and often fundainentally imconipatible-policy preferences.

31. Nor do I think that the CTA precludes the Commission from adopting quantitative and qualitative standards. See 47 U.S.C. $\S \S 303 a, 303 b$ (1988). The 1990 Act in no way restricts or circumscribes the Commission's powers under other provisions of the Communications Act of 1934. In turn, the Communications Act of 1934 vests the Commission with very broad discretion-discretion sufficient to authorize the adoption of rules of this sort. See 47 U.S.C. $\S \S 154(i), 303,307$ (a). 
enjoy the same First Amendment rights as newspapers and other kinds of media. ${ }^{32}$

Positing a umitary ${ }^{33}$ theory of the First Amendment does not necessarily imply that government cannot regulate television broadcasters in significant ways. Even under such a theory, certain kinds of speech receive varying degrees of protection from government regulation: Obscene, indecent, and commercial speech all enjoy reduced First Amendment protection from that accorded public or pohtical speech. Much of what broadcasters do seems more akin to commercial than noncommercial speech ${ }^{34}$-at least insofar as children's programming issues are concerned. Thus, regulations of the sort permissible under Central Hudson Gas \& Electric Corp. v. Public Services Commission ${ }^{35}$ should survive constitutional scrutiny when applied to children's television. The current proposals appear to be consistent with Central Hudson. ${ }^{36}$

The second question, whether the proposals will actually work, goes to the desirability of the proposed rules as a matter of sound public pohicy. ${ }^{37}$ Because this issue is one of public policy, rather than law, the Commission enjoys broad discretion in decidmg whether or not the rules are satisfactory. ${ }^{38}$ Notwithstanding this

32. See Red Lion Broadcasting Co. Inc. v. FCC, 395 U.S. 367, 387-90 (1969) (holding that the scarcity of electromagnetic spectrum justifies greater governmental regulation of the editorial policies and practices of radio and television broadcasting); $c f$. Mark S. Fowler \& Daniel L. Brenner, A Marketplace Approach to Broadcast Regulation, 60 TEX. L. REV. 207, 209-13, 221-30 (1982) (arguing that the public trusteeship model of broadcasting has failed and should be replaced with a pure market-based approach); Thomas G. Krattenmaker \& Lucas A. Powe, Jr., Converging First Amendment Principles for Converging Communications Media, 104 YALE L.J. 1719, 1726-33 (1995) (arguing that broadcasters should not be subject to a special First Amendment framework).

33. Throughout this Comment, I will use the term "unitary First Amendment" to describe a First Amendment regime under which broadcasters' First Amendment rights would be solely a function of the nature of the speech activity at issue, rather than a function of the medium through which the speech is disseminated. Cf. Red Lion, 395 U.S. at 367 (upholding the Commission's Personal Attack Rule, a surviving aspect of the now-defunct fairness doctrine).

34. See infra notes $93-161$ and accompanying text.

35. 447 U.S. 557 (1980) (providing test for determining whether commercial speech regnlation is constitutionally permissible); see also infra notes 163-86 and accompanying text.

36. See infra notes 193-203 and accompanying text.

37. See generally Motor Vehicle Mfrs. Ass'n v. State Farm Mut. Ins. Co., 463 U.S. 29, 41-44, 57 (1983) (stating that agency must explain rationale for choosing a particular action).

38. See Chevron U.S.A., Inc. v. Natural Resources Defense Council, Inc., 467 U.S. $837,860-66$ (1984) (holding that regulatory agencies may determine appropriate policy is- 
discretion, if the Commission wishes to enjoy the continued support of both the industry it regulates and the general public, it inust choose wisely among its available regulatory options.

This Comment concludes that the market has failed to provide an adequate supply of children's educational prograinining. ${ }^{39}$ However, good reasons exist to question whether the Commission's current proposals reflect the best regulatory response to this inarket failure. ${ }^{40}$ Accordingly, the Commission should consider pursuing alternative solutions, including taking actions that would increase cooperation between commercial and public television broadcasters in meeting the educational programming needs of children. ${ }^{41}$

Former Chairman Minow once described the Commission as "a vast and sometimes dark forest, where FCC hunters are often required to spend weeks of [their] time shooting down inosquitoes with elephant guns." ${ }^{42}$ If Chairman Hundt is indeed serious about addressing the paucity of children's educational programming, he would do well to consider Minow's metaphor, for the inosquitoes are sure to be thick. ${ }^{43}$ As we enter the thicket, we inust keep in mind the stakes of the game: our children and our First Amendment. I firmly beheve that we need not sacrifice one in order to safeguard the other.

\section{THE Big BAD Wolf, GRANNy, AND LITTLE RED RIDING HOOD: RENT-SEEKING BROADCASTERS AND THE FIRST AMENDMENT}

Television broadcasters routinely have attempted to cloak theinselves in Grauny's clothing by arguing that they oppose gov-

sues when Congress's statutory commands are vague).

39. See infra notes $206-15$ and accompanying text.

40. See infra notes $218-31$ and accompanying text.

41. See infra notes $232-47$ and accompanying text.

42. Newton N. Minow, Equal Time: The Private Broadcaster and the PubLIC INTEREST 258-59 (1964).

43. The Commission began admonishing broadcasters about the children's programming component of their "public interest" duties as early as 1952. See Comments of the United States Catholic Conference, In re Policies and Rules Concerning Children's Television Programming, MM Docket No. 93-48, at 3 (FCC May 7, 1993). It began a concerted campaign for improvement in 1974. See id. For a brief history of the Commission's efforts in this area, see id. at 3-5; see also In re Children's Television Programming and Advertising Practices, 96 F.C.C.2d 634, 634-38 (1984) [hereinafter Children's Programming and Advertising Practices]. 
ernment regulation of their programming decisions only because of their strong commitment to defending core First Amendment principles. ${ }^{44}$ At least one mennber of the Commission appears to view these arguments as dispositive of the current Commission's ability to impose quantitative and qualitative children's programming standards. ${ }^{45}$ Moreover, the broadcasters' position also lias enjoyed the support of at least some in the academic commumity. ${ }^{46}$ Nevertleless, even if one posits a unitary theory of the First Amendment that is fully applicable to broadcasters, ${ }^{47}$ it is unclear that broadcasters' selection of children's programming constitutes noncommercial speech activity. ${ }^{48}$

\section{A. Deconstructing Broadcasters' Claims to First Amendment Pro- tection for Programming Selections}

The modern history of commercial television broadcasters and the First Amendment begins with Red Lion Broadcasting Co. $v$. FCC. ${ }^{49}$ Red Lion involved a challenge to the constitutionality of one aspect of the Commission's "fairness doctrine," the right to reply to a personal attack broadcast by a radio or television station. ${ }^{50}$

The Commission licensed Red Lion to operate WGCB, a radio station in rural Pennsylvania. The station aired a broadcast by the Reverend Billy James Hargis, in which Hargis attacked the character of Fred J. Cook, the author of a critical biograpliy of then-Senator Barry Goldwater. ${ }^{51}$ The Commission ordered the

44. See Comments of the NAB, supra note 23, at 13-17.

45. See Ongoing Children's TV Proceedings, supra note 19, at 6359-61 (separate statement of Commissioner James H. Qnello); Quello, supra note 25, at 3-4, 14, 23.

46. See Statement of Professor Rodney A. Smolla in Support of the Comments of the NAB, Comments of the NAB, supra note 23, at attachment 6 (arguing that the Commission's proposals violate the First Amendment); see also KRATTENMAKER \& POWE, supra note 9, at 55-57, 305-31; Krattenmaker \& Powe, supra note 32, at 1721-33; Thomas G. Krattenmaker \& Lucas A. Powe, Jr., Televised Violence: First Amendment Principles and Social Science Theory, 64 VA. L. REV. 1123, 1268-70 (1978); cf. Entman, supra note 25 , at 73.

47. See, e.g., KRattenmaker \& Powe, supra note 9, at 229-36, 324-25; Fowler \& Brenner, supra note 32, at 230-42; but see Charles D. Ferris \& Terrence J. Leahy, Red Lions, Tigers and Bears: Broadcast Content Regulation and the First Amendment, 38 CATH. U. L. REV. 299, 322-23 (1989) (arguing that broadcasting is not a perfectly competitive market because participants may not freely enter and exit).

48. See infra notes $148-52$ and accompanying text.

49. 395 U.S. 367 (1969).

50. See 47 C.F.R. § 73.1920 (1995); see also 47 U.S.C. §§ 312, 315 (1988).

51. See Red Lion, 395 U.S. at 371-72. For a more complete history of the facts and 
station to provide Cook with free airtime to respond to Hargis' disparaging remarks; WGCB refused to comply with the order. The dispute ultimately reached the Supreme Court, which had to decide whether the Commission could constitutionally order a broadcaster to provide free airtime to a person subjected to a personal attack.

Without a single dissent, the Supreme Court concluded that the Commission's fairness doctrine policies "enhance[d] rather than abridge[d] the freedoms of speech and press protected by the First Amendment." ${ }^{.52}$ Relying upon a theory of spectrum scarcity, the court reasoned that not everyone wishing to operate a television or radio station may procure a hicense to do so..$^{53}$ Accordingly, those who do procure such licenses have an obligation to operate in the "public interest" by airing diverse points of view. ${ }^{54}$

The court explamed that $m$ order to ensure a robust marketplace of ideas on the airwaves, government must regulate the programming decisions of broadcasters. ${ }^{55}$ "There is no sanctuary in the First Amendment for unlimited private censorship operating in a medium not open to all." 56 Thus, unlike those publishing newspapers, broadcasters "using scarce radio frequencies" serve as "proxies for the entire community, obligated to give suitable time and attention to matters of great public concern."

Red Lion seenied to imply that radio and television broadcasters did not enjoy the same First Amendment protection as newspapers and other media. The Supreme Court made this implicit premise exphicit in Miami Herald Publishing Co. v. Tornillo. ${ }^{58}$

In Tornillo, the Supreme Court considered the constitutionality of a Florida statute that created a right of reply for pohitical candidates who were disparaged or whose opponents were endorsed in newspapers published within the state. ${ }^{59}$ The Suprene Court unanimously held that the statute violated the First Amend-

circumstances surrounding Red Lion, see POWE, supra note 9, at 37-45, 111-17.

52. Red Lion, 395 U.S. at 375.

53. Id. at $375-76$.

54. Id. at $386-90$.

55. Id. at $390-92$.

56. Id. at 392; see also NBC v. United States, 319 U.S. 190, 226-27 (1943).

57. Red Lion, 395 U.S. at 394.

58. 418 U.S. 241 (1974).

59. Id. at 243-44. 
ment rights of newspaper publishers. ${ }^{60}$ The court made no effort to square this holding with its prior decision in Red Lion, perliaps because it viewed the distinction between broadcasting and newspaper publishing as self-evident. Because anyone may establish a newspaper, the government cannot constitutionally require that existing newspapers print replies from disgruntled candidates for political office. ${ }^{61}$

Notwitlistanding Red Lion, commercial television broadcasters' basic claim to full First Amendment protection is relatively straightforward and lias strong superficial appeal: Broadcasters, like any otller participant in the marketplace of ideas, ${ }^{62}$ have a First Amendment riglit to select material that they deem best for broadcast on their licensed cliamels. Supporters of this approach argue for a unitary First Amendinent; tliat is, they reject tlie notion that the public nature of the airwaves or the scarcity of television licenses justifies placing a liglier regulatory burden on broadcasters' editorial policies. ${ }^{63}$

Under this approacl, a non-trivial restriction on broadcasters' editorial clioices is an impermissible violation of core First Amendment values. ${ }^{64}$ Furtlierınore, there is no reason to believe that the government knows better than broadcasters what programming the public wants to see-the market, rather than the government, should decide what the public shall view. ${ }^{65}$ Such argunients from a unitary First Amendment make sense, for if scarcity is the rationale for Red Lion, Tornillo was wrongly decided. ${ }^{66}$

60. Id. at 254-58.

61. See POWE, supra note 9, at 228-30, 239.

62. See Abrams v. United States, 250 U.S. 616, 624 (1919) (Holmes, J., dissenting); Gitlow v. New York, 268 U.S. 652, 672 (1925) (Holmes, J., dissenting); Whitney v. California, 274 U.S. 357, 372 (1927) (Brandeis, J., concurring).

63. KRATTENMAKER \& POWE, supra note 9, at 229-36, 317-25; cf. Turner Broadcasting Sys., Inc. v. FCC 114 S. Ct. 2445 (1994) (rejecting the argument that must-carry provisions applied to cable broadcasters deserve a lower level of First Amendment scrutiny); FCC v. League of Women Voters, 468 U.S. 364 (1984) (applying an intermediate scrutiny standard to a federal statute banning editorializing by noncommercial educational television stations that receive federal funds); Red Lion, 395 U.S. at 367 (creating a separate First Amendment standard for broadcasters and upholding the FCC's Personal Attack Rule under that standard).

64. See Statement of Professor Rodney A. Sinolla, supra note 46, at 14-24.

65. See KRATTENMAKER \& POWE, supra note 9, at 245-46, 309-15; Krattenmaker \& Powe, supra note 32 , at $1728-30$.

66. Compare Red Lion, 395 U.S. at 388-89 with Tornillo, 418 U.S. 241; see also WILLIAM W. VAN ALSTYNE, INTERPRETATIONS OF THE FIRST AMENDMENT 68-85 (1984). In most major markets, only a single newspaper exists. Moreover, the practical barriers to 
Those who have attempted to defend Red Lion generally have done so on the basis that a broadcast license empowers the holder to participate in the inarketplace of ideas with greater presence than other speakers. ${ }^{67}$ Because one generally cannot broadcast a inessage without access to an assigned band of spectrum, the government is justified in imposing a variety of public interest limitations on those liolding such licenses. ${ }^{68}$

This view fails to take into account the seismic changes that have occurred in the technologies that facilitate tlie communication. In addition to broadcast television, cable now offers dozens (and soon liundreds) of potential platforms for speecl activity, often including local "public access" charmels. ${ }^{69}$ Direct broadcast satellite (DBS), wireless cable, and video dialtone services all offer (or soon will offer) platforms for the dissemmation of ideas. Perhaps the inost accessible is the Internet. Anyone can create a home page, including botll video and audio inaterials. ${ }^{70}$ Today, a

market entry are steep. It borders on the ludicrous to suggest that there is a meaningful ability to establish a paper to rival, say, the Washington Post or New York Times. The dominant paper in a given market enjoys a larger circulation, higher visibility, and easier access to advertising revenue. See KRATTENMAKER \& POWE, supra note 9, at 214-16. Moreover, even if one could establish a rival paper with an alternate editorial poimt of view (e.g., the Washington Times), stories appearing in the rival publication will not reach the same audience, or have the same impact, as stories appearing in the dominant newspaper. Hence, a "balanced" story in the Washington Post lias more punch than a "correction" or "alternate point of view" story in the Washington Times. With the exception of Washington, Chicago, and New York, most Aunerican cities lave only a single daily newspaper.

67. See VAN ALSTYNE, supra note 66, at 85-90; Owen M. Fiss, Free Speech and Social Structure, 71 IOWA L. REV. 1405 (1986); Fiss, supra note 16, at 786-88.

68. See VAN ALSTYNE, supra note 66, at 88-90; Cass R. Sunstem, Half-Truths of the First Amendment, 1993 U. CHI. LEGAL. F. 25, 32-36; Fiss, supra note 16, at 785-88.

69. For example, the local public access cliannel in Indianapolis appears to have more than ample capacity to accommodate all comers. For large periods of prime time, the channel is unused or sinply rerums the same show over and over again. See generally Lawrence H. Winer, The Signal Cable Service Sends Part I: Why Can't Cable Be More Like Broadcasting?, 46 MD. L. REV. 212, 241-45, 277 (1987) (arguing that universal cable service, imcluding public, educational, and government cliannels, has significantly weakened Red Lion's scarcity rationale by providing "considerable opportunity for public access, whether or not mandated").

70. Significantly, all of the major presidential campaigns have established home pages on the Internet. T.R. Reid, The Candidates Invite You Into Their Home Page, WASH. PosT, Nov. 13, 1995, \& F, at 17; Nathaniel Slieppard, Jr., New Technology Offers Avenue for Old-Time Political Pranks, CHI. TRIB., Nov. 1, 1995, § 1, at 23. The Internet makes the dissemination of ideas virtually cost-free, and represents the 21st century equivalent of the street-corner of yore. Those with a serious interest in First Amendinent jurisprudence will need to adjust their paradigms accordingly. See, e.g., Owen M. Fiss, In Search 
would-be "broadcaster" has far more effective tools readily at hand to disseminate his message effectively to a wide audience than a would-be pubhsher. ${ }^{71}$ It therefore makes hittle sense to contimue holding television broadcasters hostage to some sort of second class status under the First Amendment on the theory that they hold an effective monopoly on access to the marketplace of ideas. ${ }^{72}$

The argument that the electromagnetic spectrum is a "public facility" also tends to prove too much. Virtually every "private" activity rehes upon some form of imdirect government assistance to facilitate its operations: the use of the city streets and sidewalks, rehance on public fire and pohice protection services, and so on. These are not unlimited resources, and their finite nature generally is not thought to justify governmental establishment of contentbased speech regulations incident to their use. ${ }^{73}$

The evolution of telecommunications services has also overtaken Red Lion's distinction between print and broadcast media. National newspapers, like the New York Times, the Wall Street

\section{of a New Paradigm, 104 YALE L.J. 1613 (1995).}

71. In addition to the communication delivery systems mentioned above, videocassette technologies, CD-ROMs, laser discs, and similar technologies provide additional means of program delivery. Other near-term technological developments, including digital broadcasting and digitally-compressed cable systems, will expand further consumers' access to programming through existing program delivery systems. Accordingly, concern about effective "private censorship" by broadcasters now seems misplaced. But see FCC v. League of Women Voters, 468 U.S. 364, 376 n.11 (1984); Red Lion, 395 U.S. at 392-95. The Supreme Court appears to be well aware of the intellectual infirmities of the scarcity rationale, but has not yet been willing to abandon the doctrine. See Turner Broadcasting Sys., Inc. v. FCC, 114 S. Ct. 2445, 2457 (1994). For more specific criticism of the scarcity rationale, see William T. Mayton, The Illegitimacy of Public Interest Standard at the FCC, 38 EMORY L.J. 715, 718-19 (1989); Matthew L. Spitzer, The Constitutionality of Licensing Broadcasters, 64 N.Y.U. L. REV. 990, 1007-20 (1989); Winer, supra note 69, at 215-40.

72. Indeed, cable providers have avoided the Red Lion trap. Unlike broadcasters, cable providers enjoy full First Amendment rights. See Turner Broadcasting, 114 S. Ct. at 2456-57 (dechining to apply the scarcity rationale to justify lessened First Amendment rights for cable providers).

73. For example, if a municipahty permitted candidates for political office to post signs on publicly-owned utility poles, could it condition the grant of such permission on the inclusion of "no smoking" slogans on the political materials? Assune further that there are a larger nunber of candidates seeking to use the poles designated for this use than there are available utility poles. The government may be free to permit or prohibit the use of the utility poles for the posting of signs as it thinks best, but it cannot use the scarcity rationale to justify imposing content-based speech regulations on the potential users of the poles. See City Conncil of Los Angeles v. Taxpayers for Vincent, 466 U.S. 789, 808-09 (1984). 
Journal, and USA Today, rely on access to wireline and wireless communications to facilitate their newsgathering, printing, and distribution operations. Absent access, they would be unable to nraintain their national newsgathering, production, and distribution systems. ${ }^{74}$ If the mere use of "scarce" electromagnetic spectrum justifies the imposition of government regulation, these newspapers should be subject to greater government control. ${ }^{75}$

In fact, the scarcity rationale has never withstood close scrutiny from an economic perspective. ${ }^{76}$ As early as 1959 , Professor Ronald Coase debunked the notion that the spectrum was more scarce than any other kind of finite resource in the economy. ${ }^{77}$ Spectrum, like any other component needed for the manufacturing or distribution of a product, theoretically could be bought and sold like any other commodity.

Consider newsprint. If the deniand for newsprint exceeds the available supply, the price of newsprint will rise and those newspapers willing and able to pay a higher price will obtain the newsprint needed to publish. Marginally profitable publications, on the other liand, will be priced out of the inarket and will probably cease publication-at least until prices fall. The fact that price effectively controls access would not justify government regulation

74. Peter E. Dyson \& Rosanne Rossello, Electronic Delivery Without the Internet, THE SEYBOLd REPORT ON PUBLISHING SYSTEMS, Sept. 1, 1995, at 19 (describing a wireless newspaper delivery systein); Toin Kerver, Printing By Satellite, SATELITE COMMS., Aug. 1989, at 29 (reporting on major newspaper's reliance on satellite communications); Clinton Wilder, The Media's New Message, INFORMATIONWEEK, Oct. 10, 1994, at 128 (reporting that the Gannett and Knight-Ridder newspaper chains "use satellite transmission and soplisticated electronic publisling teclnology to distribute information and publish newspapers around the country"). Most newspapers have invested in "online" services to provide subscribers with an electronic newspaper. See Tun Jones, Papers Try to Pick Up Wall Street's Beat, CHI. TRIB., Dec. 10, 1995, § C, at 1. Again, these operations are likely to involve the use of spectrum at sonte point in the creation or distribution process. The accident of spectrum use should not, however, subject newspapers providing suclı services to burdensome government regulations.

75. It was just this sort of incidental use of the electroinagnetic spectrum that led the Commission to assert jurisdiction over cable systems in the 1950s. See PowE, supra note 9 , at $216-26$.

76. See R.H. Coase, The Federal Communications Commission, 2 J. LAW \& ECON. 1, 18-20 (1959); Thoinas W. Hazlett, The Rationality of U.S. Regulation of the Broadcast Spectrum, 33 J.L. \& ECON. 133 (1990). For a relatively recent dissenting point of view, see Ferris \& Lealy, supra note 47, at 315-17 (arguing for the continuing viability of the scarcity rationale).

77. Coase, supra note 76 , at $18-20$. 
of newsprint on the theory that newsprint is scarce. The same analogy holds true for the electromagnetic spectrum. ${ }^{78}$

In hight of the foregoing, it would seem that the proponents of a market-based approach to the regulation of broadcasters are correct in positing a umitary theory of the First Amendment. ${ }^{79}$ As noted above, technological advances have largely, if not completely, undermined the scarcity rationale of Red Lion-and the scarcity rationale long ago lost whatever patina of intellectual respectability it once possessed. ${ }^{80}$

Nevertheless, the exact nature of commercial television broadcasters' First Amendment claims deserves closer scrutiny than either the Commission or the academy has undertaken. ${ }^{81}$ In particular, the "marketplace of ideas" paradigm of the First Amendment $^{82}$ presupposes that the person who is speaking actually advocates a particular idea or point of view. That is to say, it assumes that those in the marketplace mean what they say, and that their motivation for speaking is not merely to facilitate a commercial transaction. Thus, if I sell condominium time-share agreements through telemarketing, I engage in "speech" activity incident to each commercial transaction. However, the sort of speech that I engage in incident to my business (e.g., cold-calling senior citizens in New Jersey) historically has never been thought to enjoy strong First Amendment protection. ${ }^{83}$

78. See PowE, supra note 9, at 200-09; Coase, supra note 76, at 14 .

79. In my view, the "marketplace of ideas" paradigm for the First Amendment is the best model. To be sure, the Amendment does not guarantee a happy outcome; it is a gamble on the basic rationality of human beings. The principal competing vision of the First Amendment, the so-called "Civic Republican"/Madisonian" view, smacks of Plato's Republic, in which the government works diligently to make its citizens good. See, e.g., SUNSTEIN, supra note 9, at 67-77, 81-92, 241-52 (1993) (explaining that under the Madisonian view, deliberative democracy requires respect for considered judgments, rather than private consumptive choices).

80. See SUNSTEIN, supra note 9, at 54-55 (1993); see generally MNOW \& LAMAY, supra note 2 , at $66-67$.

81. See Entman, supra note 25, at 73-75; cf. Statement of Professor Rodney A. Smolla, supra note 46, at 6-10 (arguing for full First Amendment protection without any analysis of the proper First Amendment status of commercial broadcasters' speech activities).

82. See VAN ALSTYNE, supra note 66, at 34 n.38 (1984); see also Whitney v. California, 274 U.S. 357, 375-76 (1927) (Brandeis, J., concurring); Gitlow v. New York, 268 U.S. 652, 673 (1925) (Holmes, J., dissenting); Abrams v. United States, 250 U.S. 616, 630 (1919) (Holmes, J., dissenting).

83. See Valentine v. Chrestensen, 316 U.S. 52, 54 (1942) (holding that local governments may generally regulate speech activity directly associated with promoting one's 
In the case of broadcasters, much of their speech activity exists largely, if not completely, to facilitate what are essentially commercial transactions: the bundling and sale of mass audiences to advertisers. ${ }^{84}$ Most (but not all) of their programming is offered to the public solely as a derivative of their efforts to sell advertising time. Any intellectually defensible theory of broadcasters' First Amendment rights inust reflect this reality. ${ }^{85}$

The "infomercial" provides telling proof of this phenomenon. Most broadcasters are quite willing to preempt their regular programming in order to air thirty- and sixty-minute commercials-programs that consist entirely of staged testimonials for wrinkle creams, exercise inachines, and other products. That broadcasters are willing to preempt their regular programming for such fare says soinething quite significant about the value broadcasters place on their regular programming, and their motivations for showing it. Even the networks, if offered sufficiently high rents, will preeinpt prime time programming for televangelists, rich millionaires who wish to be President, and presumably for a particularly well-funded nanufacturer with a new product to sell. ${ }^{86}$ Broadcasters, unlike the print media, cannot plausibly hold themselves out to be full participants in the marketplace of ideas, at least insofar as "full participation" posits something more than a desire to complete a commercial transaction. ${ }^{87}$

business); see also Alex Kozinski \& Stuart Banner, The Anti-History and Pre-History of Commercial Speech, 71 TEx. L. REv. 747, 755-69 (1993).

84. Most editorial decisions are driven by market demand for particular programming and a desire to maximize advertising revenue by selling advertising time associated with programming that enjoys large mass audiences. See ROGER G. NOLL, ET. AL., ECONOMIC ASPECTS OF TELEVISION REGULATION 10-11 (1973); see also Comments of the Center for Media Education et al., In re Policies and Rules Concerning Children's Television Programming, MM Docket No. 93-48, at 6-9 (FCC Oct. 16, 1995); SuNSTEIN, supra note 9 , at 17-18. Of course, some of these same criticisms arguably apply to the print media. See infra notes 87, 98.

85. Dean Krattenmaker and Professor Powe have acknowledged the potential applicability of the commercial speech doctrine to television broadcast programming, but have not explored the idea. See KRATTENMAKER \& Powe, supra note 9, at 317 n.69.

86. One could imagine the Coca-Cola corporation buying a 30-minute slot of prime time to introduce "new New Coke."

87. Not all print inedia outlets are created equal. Numerous periodicals consist of nothing but commercial speech: Harmon Homes Guides, Thrifty Nickel advertisers, and Weekly Auto Traders consist completely of advertisements. The fact that they are "newspapers" or "magazines" does not transform their content. Academic writers tend to use newspapers like the New York Times and the Washington Post as examples of "the press." The reality of the marketplace is that newspapers and magazines exist along a 
Of course, notable exceptions exist to this model of the broadcaster as the relentless rent seeker. Network (and to a lesser extent local) news programming, certain educational and investigative programming, and other similar shows require the broadcaster to make political, philosophical, and artistic decisions. ${ }^{88}$ Many of these decisions are inade free and clear of any specific commercial objective. ${ }^{89}$ Thus, there are instances in which a broadcaster is not indifferent about the content of his programming; in such instances, broadcasters should enjoy the saine speech rights as print journalists, cable providers, and other media outlets. ${ }^{90}$ The

broad continuum, and some of them exist largely, if not completely, to facilitate commercial speech. Moreover, to the extent that the "responsible" or "mainstream" press rests editorial decisions on purely commercial grounds, its claims of First Amendment protection for such materials should be analyzed under the rubric of commercial speech-just like those of commercial broadcasters. See, e.g., Jeanie R. Kasindorf, What Makes Steve Run?, FORTUNE, Feb. 5, 1996, at 58, 67-69 (arguing that Forbes magazime permits its commercial objectives to control its editorial policies); John Marks \& Michael Barone, Unfriendly Fire on the Rising Star, U.S. NEWS \& WORLD REPORT Jan. 29, 1996, at 36, 37 (discussing the charges raised by Kasindorf).

88. But see Entman, supra note 25 , at 79 ("Recent research suggests reasons to fear for reporters' and even pubhishers' autonomy, with advertising revenues stagnating or shrinking and news organizations being forced to become more responsive to advertiser complaints."); Sunstein, supra note 68, at 34 (noting the power of advertisers over programming content).

89. The CBS Evening News does not select its stories based on potential Nielsen ratings. Instead, the producers and directors of the news select and air stories that they believe merit placement on the national agenda. Broadcast journalists take quite seriously this "agenda setting" function, and its operation is usually independent of concerns regarding ratings. See generally W. LANCE BENNETT, NEWS: THE POLITICS OF ILLUSION (1996) (exploring the impact of economic and political considerations on the gathering and presentation of news); SUNSTEIN, supra note 9, at 62 (stating that "agenda setting" creates strong public feelings not ouly about the news itself, but also about how the government should respond to these issues). Thus, im producing their evening news shows, networks are doing more than bundling and selling an audience. However, advertisers historically have exercised control even over the presentation of news programming. See DAVID BRINKLEY, DAVID BRINKLEY: A MEMOIR 66-67 (1995) (describing R.J. Reynolds' influence over the NBC mightly news in the 1950s). More recently, both the $A B C$ and CBS news departments have responded to pressure from tobaceo companies. See William Glaberson, '60 Minutes' Case Part of a Trend of Corporate Pressure, Some Analysts Say, N.Y. TIMES, Nov. 17, 1995, § B (Magazine), at 14; Marc Gunther, A Big Chill: Critics Say Networks Are Afraid to Investigate the Tobacco Industry, CHI. TRIB., Nov. 30, 1995, $\S 1$, at 15; see also BEN H. BAGDIKIAN, MEDIA MONOPOLY 172 (1992).

90. Freedom of Expression Act of 1983: Hearings on S. 1917 Before the Senate Comm. on Commerce, Science, and Transportation, 98th Cong., 2d Sess. 238, 240 (1984) (letter from Mark S. Fowler, Chairman, FCC to Senator Bob Packwood, Chairman, Committee on Commerce, Science, and Transporation). But cf. Irwin Safchik, Will Local Newscasts Take the High Road or the Low Road? Or Both?, THE QUILL, Sept. 1989, at 41 (quoting Van Gordon Sauter, forner president of CBS News: "For better or for 
difficulty, of course, is identifying those instances in which a broadcaster is acting with a non-commercial motivation. ${ }^{91}$ Broadcasters cannot seriously assert that all of their editorial decisions are non-commercial in nature, and, with respect to children's television programming, it is relatively clear that broadcasters are principally engaged in commercial speech activity. ${ }^{92}$

\section{B. Broadcasters' Speech Activities Should Often Be Deemed Com- mercial Speech}

As the preceding discussion suggests, even if one adopts a unitary theory of the First Amendment-tossing Red Lion and its progeny onto the dust heap of constitutional history-the First Amendment analysis is not necessarily as easy as some have suggested. ${ }^{93}$ In arguing for a inarket-based approach to the selection of television programming, Dean Krattenmaker and Professor Powe acknowledge that audiences-or the absence of theinlargely drive broadcasters' programming decisions. ${ }^{94}$ A broadcaster's parainount objective is the creation and inaintenance of an audience possessed of certain demographic characteristics. ${ }^{95}$

In most instances (and certainly in their selection of children's television programming ${ }^{96}$ ) broadcasters are largely indifferent to the content of their programming, so long as the programming

worse ... I think we are going to see a move toward [local] news broadcasts that are fashioned in direct response to marketing opportunities and audience imterest.").

91. See infra notes $148-59$ and accompanying text.

92. See infra notes $151-56$ and accompanying text; see generally MINOW \& LAMAY, supra note 2 , at 10-11, 40-42 ("Children are treated as a market to be sold to advertisers."); James B. Twitchell, Carnival Culture: The Trashing of TASTE IN AMERICA 246-47 (1992) (discussing the recent increase in commercially-based children's programs).

93. See KRATtENMAKER \& POWE, supra note 9, at 202, 229-36, 323-24; Krattenmaker \& Powe, supra note 32 , at 1726-33.

94. See Krattenmaker \& Powe, supra note 32 , at 1728-30.

95. See Bob Shanks, The CoOl FIRE: How to MAKe IT IN Television 98 (1976) (quoting an industry executive who reported that commercial television broadcasters' paramount criterion in selecting programming should be "attract[ing] mass audiences" in a fashion that would make the audience "receive, recall, and respond to the commercial messages").

96. Not only do broadcasters select children's programming based on the rents that they can obtain by broadcasting a particular show, but those producing the programming often create the shows for the express purpose of promoting various products, notably including children's toys. See MINOW \& LAMAY, supra note 2, at 45-46, 52-57; Peggy Charren, Children's Advertising: Whose Hand Rocks the Cradle?, 56 U. CIN. L. REV. 1251, 1252-55 (1988). 
generates and sustains sufficient advertiser support. ${ }^{97}$ Although the Supreme Court has consistently relied on the scarcity rationale to justify imposing special burdens on the speech rights of broadcasters, the commercial speech doctrine provides a more analytically sound basis for justifying government regulation of broadcasters. $^{98}$

However, in order to shift away from the scarcity model to a commercial speecl regime, two obstacles have to be overcome. First, a sufficiently precise definition of "commercial" speech is needed to ensure that broadcasters' non-commercial (i.e., political, social, philosophic, and aesthetic) speech activities are sufficiently protected-we should not throw out the baby with the bathwater. Second, we must be comfortable with the decision to assimilate much of what broadcasters do into the "commercial" speech category.

\section{Defining Commercial Speech. Although the Supreme Court} lias a well-developed jurisprudence with whicl to analyze governmental burdens imposed on "commercial" speech, ${ }^{99}$ it never has

97. See generally Monroe E. Price, The Market for Loyalties: Electronic Media and the Global Competition for Allegiances, 104 YALE L.J. 667, 694-95 (1994).

98. The same or similar burdens could be imposed on other media, including the press, provided that the regulations related to commercial speech activities. Historically, both judges and academics have maintained an idealized vision of the press, perhaps because most of the major press cases coming before the federal courts have involved core speech activities. See, e.g., Richmond Newspapers, Inc. v. Virginia, 448 U.S. 555, 569-77 (1980) (involving the right of newspaper persolmel and the public to attend criminal trials); Miami Herald Publishing Co. v. Tornillo, 418 U.S. 241, 247-58 (1974) (involving a "right of reply" statute triggered by a staff editorial); New York Times v. United States, 403 U.S. 713, 714 (1971) (involving publicatiou of the "Pentagon Papers," which addressed United States military policy in Vietnam); Pennekamp v. Florida, 328 U.S. 331, 346-50 (1946) (involving newspaper editorials critical of local Circuit Court judges); Bridges v. California, 314 U.S. 252, 268-78 (1941) (involving newspaper editorials relating to pending trials); Grosjean v. American Press Co., 297 U.S. 233, 247-51 (1936) (involving a punitive tax assessed agaimst nine publishers of the thirteen largest newspapers in Louisiana); Near v. Minnesota, 283 U.S. 697, 713-23 (1931) (involving newspaper reporting about police corruption and gangsterisin). However, these cases-and others like them-involve only the gathering and reporting of "hard" news; this is but a single aspect of newspaper publishing. Other related publishing activities, such as printing advertisements and "puff" pieces proinoting advertisers' businesses, have not received much First Amendment scrutiny. If there is to be a unitary First Amendment applicable to all media, the courts nuust be prepared to analyze critically the commercial or non-commercial character of various publishing activities, regardless of whether the activity is undertaken by a newspaper, a magazine, or a television station. See KRATTENMAKER \& POWE, supra note 9, at 203-36; POWE, supra note 9, at 197-215, 248-56; SUNSTEIN, supra note 9, at 108.

99. See Central Hudson, 447 U.S. 557, 564-66 (1980) (setting forth a four-part test to 
defined precisely what constitutes commercial speech, nor has it provided a set of analytical tools one can use to accurately and efficiently separate commercial speech from non-commercial speech. In fact, the Supreme Court has suggested that the distinction rests on nothing more than the application of "common sense." 100 However, this generalization does not decide concrete cases. As Judge Alex Kozinski and Professor Stuart Banner have observed, "[t]he distinction between commercial and noncommercial speech is extraordinarily difficult to make in any satisfactory way. $" 101$

Plainly, speech that sohicits customers or touts particular products is "commercial," msofar as both its primary purpose and its primary effect is to facilitate an economic transaction. ${ }^{102}$ Of course, Charles Dickens wrote his novels in order to make a living-but he did not write "A Christmas Carol" as an advertisement for poultry retailers. ${ }^{103}$ Similarly, Andy Warhol's "Campbell's Soup Cans" are works of art, notwithstanding their commercial subject matter; accordingly, they should and do enjoy full First Amendinent protection.

determine the validity of governmental restrictions on commercial speech); see also Rubin v. Coors Brewing Co., 115 S. Ct. 1585 (1995) (applying the Central Hudson test to a federal law prohibiting beer labels froin displaying alcohol content); Cincinnati v. Discovery Network, Inc., 507 U.S. 410 (1993) (applying the commercial speech doctrine to a local prohibition of "commercial handbills" on public property); Board of Trustees v. Fox, 492 U.S. 469 (1989) (applying the commercial speech doctrine to in-person commercial solicitations in student housing at a state-sponsored university).

100. See Ohralik v. Ohio State Bar Ass'n, 436 U.S. 447, 455-56 (1978); Virginia State Bd. of Pharmacy v. Virginia Citizens Consumer Council, 425 U.S. 748, 771 n.24 (1976); cf. LAURENCE H. TRIBE, AMERICAN CONSTITUTIONAL LAW, § 12-15, at 894-96 (2d ed. 1988) ("[T]he Court's blithe admonition that the difference between commercial and noncommercial speech is determined by 'common sense' has not provided reliable guidance for the resolution of individual cases.") (footnote omitted).

101. Alex Kozinski \& Stnart Banner, Who's Afraid of Commercial Speech?, 76 VA. L. Rev. 627, 641 (1990); see also Richard A. Epstein, Property, Speech, and the Politics of Distrust, 59 U. CHI. L. REv. 41, 60 (1992) (questioning the lower level of protection accorded to commercial speech in hight of the relationship between speech and property); Frederick Schauer, Commercial Speech and the Architecture of the First Amendment, 56 U. CIN. L. REv. 1181, 1184-85 (1988) ("[T]he Supreme Court, for all it has said about commercial speech, has conspicuously avoided saying just what it is.") (footuote omitted).

102. See Pittsburgh Press Co. v. Pittsburgh Comm'n on Human Relations, 413 U.S. 376, 385 (1973).

103. Upon waking up, chastened by the visits of the ghosts of Christınas past, present, and future, Mr. Scrooge instructs a neighborhood boy to buy the "prize goose" from a local shop and deliver it to Bob Cratchett's home. 
Between the easy cases of direct solicitations and works of art or hiterature hes a universe of speech that falls within a gray area. Suppose that Philip Morris purchases advertising space in the New York Times and runs the following copy: "Philip Morris supports freedom-you should too." To make the case a bit harder, we can posit that the text of the First Amendinent appears in bold letters underneath the slogan. It is possible to make good arguments for classifying the speech as both commercial and non-coinmercial. ${ }^{104}$ Central Hudson and its progeny provide little help in deciding low to analyze the lypotlietical advertiseinent.

The Supreine Court has volunteered that "commercial speech" is speech that does "no more than propose a commercial transaction." 105 Yet this distinction does not withstand close scrutiny for reasons artfully articulated by Judge Kozinski and Professor Banner. ${ }^{106}$ Similarly, other proposed distinctions between coininercial and non-commercial speech prove ephemeral. The presence or absence of a profit notive fails, for "[in]uch expression is engaged in for profit but nevertheless receives full First Ainendment protection." 107 Nor can the universe of commercial speech be linnited to speech disseminated through the use of money, speech that solicits money, or speech on a commercial subject. ${ }^{108}$

To say that any speech by a coinpany constitutes commercial speech plainly would be inconsistent witl relevant Supreme Court precedents. Corporate entities can and do engage in non-commercial speech. ${ }^{109} \mathrm{~A}$ test that hinges entirely on a speaker's subjective motivation for engaging in speech activity would create almost insurmountable difficulties in its application. ${ }^{110}$ Those engaged in

104. See Kozinski \& Banner, supra note 101, at 645-46.

105. Pittsburgh, 413 U.S. at 385.

106. See Kozinski \& Banner, supra note 101, at 639-41 (noting that many commercials do quite a bit more than merely propose a commercial transaction, but are not thought to be non-commercial speech).

107. Id. at 637.

108. See Virginia State Bd. of Pharmacy v. Virginia Citizens Consumer Conncil, 425 U.S. 748, 761 (1976); see also Kozinski \& Banner, supra note 101, at 638 (describing what commercial speech is not).

109. See First Nat'l Bank v. Bellotti, 435 U.S. 765, 769 (1978); United Mine Workers v. Pennington, 381 U.S. 657, 669-70 (1965); Eastern R.R. Presidents' Conference v. Noerr Motor Freight, Inc., 365 U.S. 127, 139-40 (1961), for examples of protected political speech by corporate entities.

110. If a bank offering an "affinity" card affiliated with a particular organization (e.g., the NAACP Legal Defense Fund) ran an advertisement promising to rebate $1 \%$ of all charges to that group, would the advertisement constitute "commercial speech." Certainly, 
commercial speech that includes an arguably non-cominercial speech element could be expected to claim routinely that the speech merited full First Amendment protection.

Indeed, one need look no farther than Valentine $v$. Chrestensen, ${ }^{111}$ the seminal case in the field of the commercial speech doctrine, for an example of such a case. Mr. Chrestensen wished to publicize the fact that he maintained a submarine that interested persons could tour for a nommal fee. ${ }^{112}$ When New York City pohice informed Chrestensen that he could not distribute leaflets touting the subinarme because they were purely "commercial," he modified the leaflets to mclude an attack on the city's prohibition on commercial leafletting on one side of the leaflets. ${ }^{113}$

The Supreme Court treated Mr. Chrestensen's leaflets as commercial speech, notwitlistanding the non-commercial element: "We need not indulge nice appraisal based upon subtle distinctions in the present instance nor assume possible cases not now presented." "114 The Court explained:

It is enough for the present purpose that the stipulated facts justify the conclusion that the affixing of the protest against official conduct to the advertising circular was with the intent, and for the purpose, of evading the prohibition of the ordinance. If that evasion were successful, every merchant who desires to broadcast advertising leaflets in the streets need only append a civic appeal, or a moral platitude, to achieve immumity from the law's command. ${ }^{115}$

Even if Mr. Chrestensen's behavior was sufficiently transparent to make the case an easy one, other, harder cases renuain.

It therefore slould coine as no surprise that some have given up trying to articulate a principled distinction between commercial and noncommercial speech. For example, Judge Kozinski concludes that the difficulties associated with defining commercial speech

the bank's motivation in running the advertisement includes a desire to issue inore LDF affinity cards. At the same time, however, the bank could reasonably claim that it wanted to pubhicize its support of the particular organization-a task that has a significant non-commercial element.

111. 316 U.S. 52 (1942).

112. Id. at 52-53.

113. Id.

114. Id. at 55.

115. Id. 
make the category at best arbitrary and at worst meaningless; he advocates its abohition. ${ }^{116}$ His argument has a good deal of persuasive force; at a theoretical level, it is rather difficult to rebut. ${ }^{117}$ However, he has ignored a rather basic empirical fact: The federal courts have successfully deployed the commercial speech doctrine for over twenty years, notwithstanding its definitional shortcomings. Along the same lines, Judge Kozinski's argument also disregards the current Supreme Court's consistent and enthusiastic application of the cominercial speech doctrine. ${ }^{118}$

As these observations suggest, I have a great deal of sympathy for Judge Kozmski's position. In the best of all possible worlds, all speech would receive full and robust First Amendment protection, regardless of the intent or purpose of the speech. This is not because all speech is inherently equal, ${ }^{119}$ but rather because government simply cannot be trusted to identify and protect various forms of social and political speech from a project of censorship or control. ${ }^{120}$ Accordingly, Judge Kozinski's approach

116. Kozinski \& Banner, supra note 101, at 651-53.; cf. Daniel A. Farber, Commercial Speech and First Amendment Theory, 74 Nw. U. L. REv. 372, 386-90 (1979) (suggesting that a principled distinction can be drawn by looking at whether the speech in question is simply informative or contractual in nature).

117. Cf. Ronald K. L. Collins \& David M. Skover, Commerce and Communication, 71 TEX. L. REV. 697, 698-99 (1993) ("[P]ublic discourse cannot be significantly separated from the influences of commercialisin."). But see Schauer, supra note 101, at 1183-93 (arguing that although it is difficult to distinguish between core communication and commcrcial speech, the distinction should be maintained).

118. See Rubin v. Coors Brewing Co., 115 S. Ct. 1585 (1995) (holding that a government ban on placing alcohol content on beer labels did not sufficiently "fit" with the government goal of preventing a "strength war" because alcohol content could be disclosed in numerous other ways); City of Cincinnati v. Discovery Network, Inc., 507 U.S. 410 (1993) (holding that a city's ban on distribution of commercial handbills did not reasonably fit with the goal of promoting the city's aesthetic beauty since newspapers, which could produce visual clutter just as easily, were permitted); Edenfield v. Fane, 507 U.S. 761 (1993) (striking down under intermediate scrutiny a Florida ban on in-person solicitation by C.P.A.s by holding that state did not show that the ban advanced the state interest in any direct or material way); Board of Trustees v. Fox, 492 U.S. 469 (1989) (holding that the proper test to be applied in the commercial speech context is not whether the restriction employs the least restrictive means, but rather whether the means employed fit reasonably with the ends sought to be achieved).

119. Alexander Meiklejohn and Owen Fiss have asserted-correctly in my view-that speech furthering self-governance lies at the core of the First Amendment. See Alexander Meiklejohn, Free Speech and Its Relation to Self-Government, reprinted in ALEXANDER

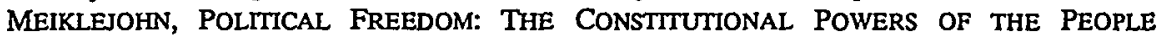
22-28 (1948); Owen M. Fiss, Silence on the Street Comer, 26 SuFfolK U. L. REv. 1, 19-20 (1992).

120. The recurrent battle over prohibiting flag burning provides a salient example of 
would best protect core speech activities from government encroachment by avoiding completely the definitional difficulties-and concomitant censorial discretion-associated with labelling particular speech "non-commercial" or "commercial."121

However, we do not live in Candide's "best of all possible worlds," and our jurisprudence must reflect this basic reality. Regardless of the ultimate merits of the commercial speech doctrine, it will be witl us for some time to come. It is therefore necessary for those of us who support a vigorous and freewlieeling marketplace of ideas to make the best of a bad situation. Given the current state of the law, we simply cannot avoid the vexing question of what constitutes "commercial speech" or, perliaps more aptly, what doesn't constitute commercial speech. ${ }^{122}$

In our nnperfect world, it is impossible to maintain a viable theory of commercial speech without substantial reliance on an intent-based test. Andy Warliol's soup cans provide an instructive illustration: We know that Andy Warhol's soup cans are "art" rather than "commercial speecli" because Mr. Warhol could not have cared less whether the works sold or promoted the sale of so inucl as a single can of soup. A reasonable person would conclude that Warhol's motivations were non-commercial. On the otler hand, a glossy advertisement in Time magazme informing us that Campbell's soup is "Mmmm Mmmm Good!" constitutes "commercial" speech precisely because we know that Caunpbell's intends its advertisement to promote or facilitate an economic transaction-even if Norinan Rockwell illustrates it. Of necessity, the application of an intent-based test also must rely rather heavily on the particular context of the speech activity to determine its commercial or non-commercial character.

In fact, it seems probable that determinations regarding the commercial or non-commercial nature of speech can rest on a "common sense" basis only if the speaker's motivation is transpar-

this phenomenon. See Katharine Q. Seelye, House Easily Passes Amendment to Ban Desecration of Flag, N.Y. TIMES, June 29, 1995, at A-1; see also Texas v. Johnson, 491 U.S. 397 (1989).

121. But cf. SUNSTEIN, supra note 9, at 149-50 (arguing that objection to First Amendment theories that rely on line drawing are "unhelpful" and noting that expansive theories of the First Amendment are still subject to "bias in administration").

122. One might say that, like Justice Potter Stewart's famous quip about obscenity, we will "know [commercial speech] when [we] see it." See Jacobellis v. Ohio, 378 U.S. 184, 197 (1964) (Stewart, J., concurring). 
ent to all. However, the apphication of "common sense" to mixedmotive cases will not lead to predictable outcomes. In such imstances, the federal courts must apply a kind of "reasonable person" standard to divine the probable motivation of the speaker, based on the particular context in which the speech activity occurred. $^{123}$

In Chrestensen, Mr. Chrestensen claimed that his revised leaflet constituted something more than inerely commercial speech; the court rejected this claim based on its perception that the noncommercial element of Chrestensen's speech was simply a fig leaf designed to avoid the proscription against commercial leafletting. ${ }^{124}$ The Court disposed of the case based on a reasonable assumption regarding Mr. Chrestensen's "intent and purpose" in engaging in the facially non-commercial speech. ${ }^{125}$ Thus, the Chrestensen Court relied on an objective evaluation of Chrestensen's intent in engaging in the speech activity to classify the activity. ${ }^{126} \mathrm{~A}$ review of the other relevant coinmercial speech cases demonstrates that an objective evaluation of the intent of the speaker is almost always dispositive in determining the commercial or non-commercial nature of particular speech. ${ }^{127}$

123. See David F. McGowan, Comment, A Critical Analysis of Commercial Speech, 78 CAL. L. REv. 359, 383-90 (1990) (arguing that the Court views "profit and the profit motive as the characteristic that distinguishes commercial speech from other types of speech"); see also Bolger v. Youngs Drug Prods. Corp., 463 U.S. 60, 66-68 (1983) (holding that the commercial nature of speech depends on a "combination" of characteristics such as content, context, and motivation); Valentine v. Chrestensen, 316 U.S. 52, 55 (1942) (holding that merchants may not evade lawful regulation of commercial advertising merely by affixing a political protest to the material).

124. 316 U.S. 52, 54-55.

125. Id. at 55 .

126. Judge Kozinski claims that the Supreme Court has explicitly ruled out intention as a test for commercial speech. See Kozinski \& Banner, supra note 101, at 639-40. In support of this proposition, he cites a single case, Virginia State Board of Pharmacy $v$. Virginia Citizens Consumer Council, Inc., 425 U.S. 748, 761-65 (1976). Kozinski \& Banner, supra note 101, at 640 . The cited pages do not contain an explicit rejection of an intent-based standard, nor is there any such prolibition in any of the other commercial speech cases. Judge Kozinski simply appears to be incorrect on this point.

127. See Board of Trustees v. Fox, 492 U.S. 469, 473-75 (1989); Bolger v. Youngs Drug Prods. Corp., 463 U.S. 60 (1983); Village of Hoffman Estates v. Flipside, Hoffman Estates, Inc., 455 U.S. 489 (1982). Elsewhere, I lave argued that the First Amendment should be applied in a context-specific fashion to provide greater access to public property for use in speech activities to certain speakers. See Ronald J. Krotoszynski, Celebrating Selma: The Importance of Context in Public Forum Analysis, 104 YALE L.J. 1411, 1425-32 (1995). In many respects, iny position on the question of commercial speech is of a piece with this earlier work; context is just as essential to drawing proper First 
Explicit adoption of an intent-based standard will not make hard cases, sucli as the Philip Morris hypothetical, substantially easier to resolve. However, it would expand the umiverse of commercial speecli to encompass inaterials traditionally thought to fall outside the category. ${ }^{128}$

The Supreme Court slould acknowledge that intent plays a crucial part in determining the commercial nature of speech. Correspondingly, the universe of non-commercial speech should encompass all speecli that a reasonable person would conclude has as its primary purpose something other than facilitating or encouraging a commercial transaction. The problem of "mixed motive" cases would be resolved by reference to the probable principal objective of the speaker. Thus, Mr. Chrestensen's protest of the prohibition against public leafletting appears to be secondary to his primary objective of publicizing his subinarine. ${ }^{129} \mathrm{Had} \mathrm{Mr}$. Chrestensen initially produced a leaflet attacking the city government's attempt to squelch commercial speech, his case would have

Amendment lines in the commercial speech area as it is in the realm of the public forum doctrine. The weaker First Amendment protectiou afforded commercial speech should apply in all instances where the motivation for the speech is commercial, rather than non-commercial. The reason for this is relatively simple: a commercial speaker is less interested in meaningful participation in the marketplace of ideas than in concluding a commercial transaction. Compare Kozinski \& Banner, supra note 101, at 648-53 (arguing that the First Amendment should be interpreted to provide identical protection for commercial and non-commercial speech since commercial matters can be as important as political, artistic, or religious matters) with MEIKLEJOHN, supra note 119, at 22-27 ("[T]hongh citizens may ... be barred from speaking, they may not be barred because their views are thought to be false or dangerous.") and Alexander Meiklejolin, The First Amendment Is An Absolute, 1961 SUP. CT. REV. 245, 255-57 (discussing how the First Amendment does not protect a universal "freedom to speak" but instead protects freedom of thought and communication).

128. For example, record labels produce music videos to promote the sale of albums. These videos are often elaborate, film-length creations, involving substantial artistic effort. However, if intent governs the classification of speech, they arguably constitute a form of commercial speech. But see Kozinski \& Banner, supra note 101, at 641. Music videos differ in this respect from most feature-length movies. Although the distinction may at first seem difficult to grasp, it is a meaningful one. A music video stands to an album the same way that a movie "trailer" or "teaser" stands in relation to a movie; it represents an attempt to entice a customer to purchase the right to hear or see the larger work. Indeed, music videos are arguably "doubly" commercial speech. MTV, VH1, the Nashville Network, and other music-video cable channels select and show the music videos that they beheve will generate the highest advertising revenue. The video channels' unwillingness to broadcast controversial materials-materials likely to spook boycott-wary advertisers-provide additional evidence of the essentially commercial nature of the undertaking.

129. Chrestensen, 316 U.S. at 53-54. 
been stronger. Doubts as to whether this is a proper approach to "mixed-motive" cases are largely resolved by reference to two commercial speech cases, both imvolving "mixed" commercial and non-commercial speech. ${ }^{130}$

Hoffman Estates v. Flipside ${ }^{131}$ imvolved a challenge to a local ordinance that made it "unlawful for any person 'to sell any items, effect, paraphernaha, accessory or thing which is designed or marketed for use with illegal cannabis or drugs . . . without obtaiming a hicense therefor." "132 The marketing restrictions imcluded display rules that prohibited the placement of certain items near or proximate to "literature encouraging illegal use of cannabis or illegal drugs."133 Flipside, a store catering to the local counterculture, claimed that the ordinance infringed its First Amendment rights by using the presence of certain literature as a test for determining whether the store was inarketing other items for an illicit use. ${ }^{134}$

The Court squarely rejected Flipside's claim, holding that the ordinance did not unconstitutionally burden "the noncommercial speech of Flipside or other parties." 135 The ordinance inerely "regulate[d] the commercial inarketing of items that the labels reveal may be used for an illicit purpose." "136 Thus, the government was free to regulate speech activities involved in facilitating commercial transactions, even if it inarginally burdened Flipside's ostensibly non-commercial speech.

In Bolger v. Youngs Drug Products Corp. ${ }^{137}$ the Court examined a challenge to a federal statute that prohibited "the inailing of nnsolicited advertisements for contraceptives."138 Youngs Drug directly marketed its prophylactic devices to the general public; the coinpany's efforts included mailings consisting of advertisements for condoms and informational pamphlets providing healthbased reasons for buying and using condoms. ${ }^{139}$ The Court faced

130. See Bolger v. Youngs Drug Prods. Corp., 463 U.S. 60, 66-67 (1983); Village of Hoffman Estates v. Flipside, Hoffman Estates, Inc., 455 U.S. 489, 496-97 (1982).

131. 455 U.S. 489 (1982).

132. Id. at 492 (citation omitted).

133. Id. at 496.

134. Id. at $495-96$.

135. Id. at 496.

136. Id.

137. 463 U.S. 60 (1983).

138. Id. at 61; see also 39 U.S.C. § 3001(e)(2) (1982).

139. Bolger, 463 U.S. at 62 . The mailings imcluded two pamphlets: "Condoms and $\mathrm{Hu}$ - 
the task of classifying Youngs Drug's informational pamphlets-was the speech activity at issue wholly commercial or commercial in part and non-commercial in part? At least one of the pamphlets at issue, "Plam Talk about Venereal Disease," did not contain any references to Youngs Drug's products. ${ }^{140}$

The Supreme Court began its analysis of the painphlets by noting that their "proper classification as commercial or non-commercial speech ... presents a [close] question."141 Nevertheless, the fact that Youngs Drug distributed the pamphlets with other promotional materials (i.e., the advertising flyers) led the Court to question the non-commercial nature of the pamphlets. The Court concluded that " $[t]$ he mailings constitute commercial speech notwithstanding the fact that they contain discussions of important public issues such as venereal disease and family planning."142 However, neither the fact that the painphlets were meant to promote Youngs Drug's products nor Youngs Drug's economic motivation for mailing the pamphlets compelled the conclusion that the pamphlets constituted "commercial" rather than "non-commercial" speech. ${ }^{143}$ The juxtaposition of facially "non-commercial" pamphlets with more direct promotional inaterials ultimately led the Court to declare that the entirety of Youngs Drug's mailings constituted "commercial speech," phlets, in a different context, would enjoy full First Amendment protection..$^{145}$

Bolger strongly suggests the commercial or non-commercial nature of speech will depend in large part on the context in which the ostensibly non-commercial speech occurs. If the speech occurs in the context of plainly commercial speech, the Court appears to be willing to assimilate the arguably non-commercial speech into the "commercial" category. Perliaps the best explanation for the Court's reasoning in Bolger is that the intent of the speaker-or more precisely the Court's determination of the speaker's probable

\footnotetext{
man Sexuality" and "Plain Talk about Venereal Disease." Id. at 66 n.13.

140. Id. at 66 n.13.

141. Id. at 66.

142. $I d_{2}$ at $67-68$ (footnote omitted).

143. Id. at $66-67$.

144. Id. at $66-68$.

145. See generally Griswold v. Connecticut, 381 U.S. 479 (1965) (holding that the dissemination of materials on birth control is protected by the penumbra of the First Amendment).
} 
intent-prefigures the characterization of particular speech as commercial or non-commercial. ${ }^{146}$ The intrinsic nature of the materials did not control the Court's speech analysis; virtually any kind of material could be commercial speech in the right context. $^{147}$

However, courts must take care not to underprotect non-commercial speech activity. Explicit use of an objective-intent test would not necessarily mean that all mixed-motive speech should be classified as commercial. The government should not be permitted to establish a general presumption that mixed-motive speech is commercial in nature. Toward this end, the federal courts should establish a clear presumption that, if speech may reasonably be characterized as either commercial or non-commercial, the speaker imtends the speecl to be non-commercial. In hard cases, the burden always should rest on the government to establish that, in a given context, particular speech is commercial rather than non-commercial. Furthermore, the government should have to do so by something inore than a mere preponderance of the evidence (for example, by clear and convincing evidence).

2. Broadcasters Are Often Engaged in Commercial Speech. Under an intent-based test for commercial speech, much of what broadcasters air would constitute "commercial" speech. ${ }^{148}$ In many respects, the programming that appears between commercials is incidental to the commercials themselves. ${ }^{149}$ It does not require

146. Another significant factor in the outcoine of commercial speech cases is the Court's assessment of the informational value of the commercial speech to the public. See Daniel H. Lowenstein, Too Much Puff: Persuasion, Paternalism, and Commercial Speech, 56 U. CIN. L. REv. 1205, 1228-30 (1988); see also Bigelow v. Virginia, 421 U.S. 809, 822 (1975) (granting First Amendment protection to an advertisement which "conveyed information of potential interest and value to a diverse audience").

147. A booklet on how to stage an effective flag buming could be "commercial" speech if sent as part of a campaign to sell American flags for such a purpose, even though the same pamphlet, if distributed mcident to a protest rally, would constitute "non-commercial" speech. It is the context in which the speech occurs, rather than the content of the speech, that is outcome-determinative. See Krotoszynski, supra note 127, at 1425-36; but cf. McGowan, supra note 123, at 400-05 (arguing that the commercial speech doctrine's scope should be significantly narrowed).

148. See Bolger, 463 U.S. at 66-68 (1983); Village of Hoffman Estates v. Flipside, Hoffman Estates, Inc., 455 U.S. 489, 495-97 (1982).

149. Indeed, in the early days of television, the line between programming and sponsorship sometimes blurred. See MINOW \& LAMAY, supra note 2, at 91, 91 n.64. David Brinkley writes of newscasts sponsored by R.J. Reynolds in which the sponsor required that the anchorman smoke or mamtain a lit cigarette throughout the entire program. 
much creativity to argue for the extension of the Bolger principle to reach broadcasting; the only salient difference is the use of the airwaves rather than the mails to deliver the advertiser's message.

With respect to the selection of particular kinds of children's television shows, a network or local broadcaster is largely indifferent as to whether it should air "Magic Smurfs" or "Rainbow Bright." If a choice between the shows must be made, the decision will probably turn on which show is likely to generate higher ratings, or generate a predictable audience of particular demographic cast (for example, young girls rather than young boys), rather than on some artistic, philosophic, or political ground..$^{150}$ Indeed, at the risk of being overbold, it is virtually certain that the network or local station will not make a decision based on the political,

BRINKLEY, supra note 89, at 66-67 (1995) (describing the nicotine-laced aesthetics of the "Camel Caravan of News" on NBC). Likewise, Mary Tyler Moore tells of serving as "Happy Hotpoint," the Hotpoint Appliances' Elf. MARY T. MOORE, AFTER ALL 61-65 (1995). Her character interacted with Harriet of "Ozzie \& Harriet" during commercial breaks in the show. Id. Finally, the very term "soap opera" is derived froin the early sponsors of these shows on radio-manufacturers of soaps and other cleaning products-that hoped to lawk their wares to housewives transfixed to their programming. See Muriel G. Cantor \& Suzanne Pigree, The SoAp Opera 36-37 (1983).

Some obvious vestiges of the early practices remain. For example, Willard Scott and Spencer Christian, weathercasters for the NBC "Today Slow" and ABC's "Good Morning America" respectively, both give direct prodnct endorsements of their sponsors' products along with their meteorological prognostications. It would be quite naive to think that less direct forms of advertiser control do not also exist. See BAGDIKIAN, supra note 89; see also Steve Johnson, Ad Nauseum: 'Friends' Crosses the Ethical Line With a Shameless Tie-In, CHI. TRIB., Jan. 26, 1996, \& 2, at 3 (deploring the intermingling of the popular television program with a Coca-Cola advertising campaign).

Some advertisers also have produced programming that they wish to have broadcast like any other syndicated show. See Sharon Edelson, That's Sell-o-Tainment, WOMEN's Wear DaILY, Apr. 26, 1994, at 16; Chuck Ross, Blurring the Line: Smith Kline's show: Informational Programming or Infomercial?, INSIDE MARKETING, May 11, 1994, at 28.

150. See MINOW \& LAMAY, supra note 2, at 10-11, 19-21; TwITCHELL, supra note 92, at 246-47 (discussing popularity of war toy-based shows). Indeed, toymakers produce and financially subsidize the distribution of many of the most popular children television shows. See Minow \& LAMAY, supra note 2, at 52-57; Charren, supra note 96, at 1252-55. Media mogul Rupert Murdoch once condemned commercial broadcasters' participation in distributing these materials in no uncertain terms:

There's nothing wrong with advertising to a child audience, but to make your programming that way I think is really a prostitution of the broadcaster's function. If you did that in a newspaper, you'd be run out of town.

The Thinking Man's Media Baron, BroadCASTING, Apr. 13, 1987, at 68, 70. Mr. Murdoch's supposition regarding such arrangennents in the national print media appears to hold true, if the scandal surrounding Forbes' editorial policies is any indication of contemporary journalistic ethics. See Kasindorf, supra note 87, at 67-69; Howard Kurtz, Forbes Feels the Wrath of Fortune, THE WASHINGTON POST, Jan. 16, 1996, at E1. 
philosophical, or artistic message each show conveys. The decision is fundamentally an economic one, more akm to a grocer deciding to stock green leaf or Romaine lettuce than to choose a political party's platform.

For example, in formal comments submitted to the Commission, Capital Cities/ABC touted a new children's television show the network was developing called "CRO" as an imdication of its strong support for educational children's programming. ${ }^{151}$ "CRO" would feature serious educational messages about "simple tools, machines, and scientific principles." cancelled "CRO" and replaced it with a cartoon version of the movie "Dumb and Dumber." $\mathrm{ABC}$ cannot argue seriously that its decision to cancel "CRO" and replace it with "Dumb and Dumber" reflected any social, aesthetic, moral, or philosophical point of view; it reflected a desire to increase revenues from the sale of commercial spots in the half-hour at issue, nothing more and nothing less.

The behavior of advertisers provides further confirmation of this model. Advertisers generally demand a guarantee that, in exchange for their advertising dollars, the station will actually deliver an audience that largely, if not completely, lives up to the station's projections. Hence, stations commonly offer free advertising time as "make-goods" for "underdehvery" of a specific kind of audience. ${ }^{154}$

151. See Comments of Capital Cities/ABC, In re Policies and Rules Concerning Children's Television Programming, MM Docket No. 93-48, at 10, 10 n.10 (FCC May 7, 1993); see also Comments of Children's Television Workshop, In re Policies and Rules Concerning Children's Television Programming, MM Docket No. 93-48, at iii, 3-4 (FCC May 7, 1993). "CRO" was a joint project of $A B C$ and the Children's Television Workshop. Comments of Children's Television Workshop, supra, at 3.

In faimess to $\mathrm{ABC}$, it bears noting that $\mathrm{NBC}$ also used its formal comments to tout a new educational show, "Name Your Adventure," that did not survive a single season. See Comments of NBC, In re Policies and Rules Concerning Children's Television Programming, MM Docket No. 94-48, at 13-15 (FCC May 7, 1993); Reply Comments of NBC, In re Policies and Rules Concerning Children's Television Programming, MM Docket No. 93-48, at 8 (FCC June 7, 1993).

152. Commeuts of Capital Cities/ABC, supra note 151, at $10 \mathrm{n.10}$; see also Comments of CBS, supra note 24, at 10-11 (describing "CRO" and touting it as an example of the commercial networks' commitment to educational children's programming).

153. See Address by Chairman Reed E. Hundt to the Kidsnet Meeting, at 2 (Aug. 22, 1995) (transcript on file with author). ABC must have counted ou the Commission having a very short institutional memory. Indeed, many networks touted "CRO" as strong evidence of the commercial networks' commitunent to compliance with the CTA, 47 U.S.C. $\S \S 303 a, 303 b$. See supra notes 151-52.

154. See Verne Gay, NBC Ratings Belly-Flop Forces Ad Make-Goods, ADVERTISING 
The transaction, at bottom, is really little different from the grocer's. ${ }^{155}$ Just as a grocer tries to maintain a produce stock that is appealing to most of his regular customers, so too a broadcaster attempts to maintain a line-up of programming that will generate the kinds of audiences his regular advertisers desire. A grocer is largely imdifferent to the items he sells, so long as his store generates a sufficient volume of sales and an acceptable level of income. Likewise, television broadcasters are often largely indifferent to the programming that they broadcast, provided advertisers are willing to purcliase spots. ${ }^{156}$ Even those who champion the speecl rights of broadcasters stipulate that broadcasters' prograinming decisions are largely, if not completely, driven by the market. ${ }^{157}$ If broadcasters are passive reactors to the public taste, the claim that they exercise meaningful editorial judgments about the content of their programming rings rather lollow.

AGE, Sept. 26, 1988, at 3 (describing process of using make-goods to satisfy advertiser's audience expectations); see also Linda Moss, Hasbro Buys Out Turner 'Toon-In' Time, MULTICHANNEL NEwS, Nov. 23, 1992, at 49 ("Advertisers are expecting to get make goods from networks because of the underdelivery of several children's shows."); Wayne Walley, Networks Fed Up, ADVERTISING AGE, May 7, 1990, at 66 ("Ratings guarantees provide for make-goods should a network show fail to dehiver an agreed-upon audience.").

155. See Fiss, supra note 67, at 1413 ("From the perspective of a free and open debate, the choice between 'Love Boat' and 'Fantasy Island' is trivial."); see also Fiss, supra note 16, at 788 ("For a businessinan, the costs of production and the revenue likely to be generated are highly pertinent factors in determining what shows to run and when ....").

156. The recent controversy over "trash" talk shows illustrates this point quite nicely. Talk shows are very inexpensive to produce, and therefore are less expensive to buy from syndicators. These shows also generate good ratings on a consistent basis. The result: advertisers purchase spots on talk shows discussing "the habits of sexaholics who choose celibacy-and those who love thein." However, after a number of public interest groups decried the content of these slows, advertisers responded by withdrawing their financial support. See Lawre Mifflin, Talk-Show Critics Urge Boycott of Programs by Advertisers, N.Y. TIMES, Dec. 8, 1995, at A-22; Dusty Saunders, Advertisers Are Backing Off From Sleazy TV Shows, CHI. TRIB., Dec. 4, 1995, § 2, at 4. The result of the advertisers' decision is that "[s]ome of the current talkers could be swept off the scliedule by next fall." Id. Broadcasters are largely, if not completely, indifferent to the content of these shows, so long as they reap the expected rents from the sale of advertising time; if the advertising support dries up, the broadcaster drops the slow. See MINOW \& LAMAY, supra note 2, at 37-39; see generally Ferris \& Leahy, supra note 47, at 324 ("Rather than generating a wider range of programming choices for the public, the uewly competitive inarket-place appears, at least in some cases, to generate programming that falls to the lowest common denominator that will attract the largest audience.").

157. See, e.g., KRATTENMAKER \& POWE, supra note 9, at 40-42, 278-83; Kratteumaker \& Powe, supra note 32, at 1728-30, 1734. 
The broadcasters' First Amendment argument boils down to the assertion that they should be free to bundle and sell audiences without government regulation. Framed in these terms, it is more an argument for economic due process than for serious First Amendment protection. ${ }^{158}$ "[T] $]$ he market brings to bear on editorial and programming decisions factors that might have a great deal to do with profitability or allocative efficiency (to look at matters from a societal point of view) but hittle to do with the deinocratic needs of the electorate.

\section{A New Paradigm for Evaluating Broadcasters' Free Speech Claims}

Both the Commission and the federal courts should reconsider the First Amendment pretensions of television and radio broadcasters. When programming decisions reflect nothing more than a desire to maximize rents, the basis for broadcasters' claim to First Amendment rights equal to those of political candidates, Hare Krishnas, or even mamstream newspapers is difficult to discern.

To be sure, this is not always the case. The production of national and local news involves the exercise of editorial judgment about what is "newsworthy," and broadcast journalists are famous for the seriousness with which they take their role in setting the public pohicy agenda. ${ }^{160}$ However, with respect to their selection of children's programming, most broadcasters, in most imstances, would be liard pressed to explain their programming choices in other than purely economic terms. ${ }^{161}$ Accordingly, the federal courts and Commission should abandon Red Lion as a justification for public-interest regulation of television and radio broadcasters in favor of rehance on the commercial speecli doctrime.

158. See Lochner v. New York, 198 U.S. 45 (1905); Nebbia v. New York, 291 U.S. 502 (1934); see generally Kozinski \& Banner, supra note 83, at 767-74.

159. Fiss, supra note 16 , at 788 .

160. See BENNETT, supra note 89 , at 26-27; SUNSTEIN, supra note 9, at 62 . Of course, broadcast journalists, particularly at the local level, sometimes tend to overstate their independence from crass commercial concerns. The broadcast newsroom aphorism that "if it bleeds, it leads" demonstrates broadcast journahists' conflicting objectives. See BENNETT, supra note 89, at 26-27; Stephen Budiansky, Local TV: Mayhem Central, U.S. NEws \& WORLD REPORT, Mar. 4, 1996, at 63-64.

161. MiNow \& LAMAY, supra note 2, at 52-57; SUNSTEIN, supra note 9, at 65-66: Charren, supra note 96 , at 1252-57. 
Although the Supreme Court has not clearly defined "commercial speech,"162 it has clearly defined the limits of the government's ability to regulate commercial speech. Under Central Hudson, a four-part test governs the legality of government-imposed burdens on commercial speech:

(1) The speech must not be misleading or false, or concern unlawful activity;

(2) The government inust proffer a substantial interest in restricting or regulating the speech;

(3) The restriction or regulation inust directly advance the government's substantial interest; and

(4) The restriction must be narrowly tailored to achieve the government's objective. ${ }^{163}$

Thus, commercial speech enjoys significant First Amendment protection, though less protection than non-commercial speech. ${ }^{164}$

Under the Red Lion line of cases, burdens on broadcasters' First Amendment rights are subject to an intermediate level of scrutiny. ${ }^{165}$ "[T] hese restrictions have been upheld only when [the Court was] satisfied that the restriction is narrowly tailored to further a substantial governmental interest, such as ensuring adequate and balanced coverage of public issues." 166 This test is, of course, remarkably similar to the Central Hudson test for burdens on commercial speech. Indeed, although the Court in FCC v. League of Women Voters did not explicitly require "narrow tailoring," it ultimately struck down a government-imposed restriction on editorializing by public broadcasting stations because "its proscription is not sufficiently tailored to the harms it seeks to prevent to justify its substantial interference with broadcasters' speech."167

162. See supra notes $99-110$ and accompanying text.

163. Central Hudson Gas \& Elec. Corp. v. Public Service Commission of NY, 447 U.S. 557, 564 (1980). The Supreme Court continues to adhere to the Central Hudson framework. See Rubin v. Coors Brewing Co., 115 S. Ct. 1585, 1589 (1995); City of Cincinnati v. Discovery Network, Inc., 507 U.S. 410, 416 (1993).

164. See, e.g., Simon \& Schuster, Inc. v. Menbers of New York State Crime Victims Bd., 502 U.S. 105, 118 (1991) (applying strict scrutiny to a content-based speech restriction, and requiring a "compelling state interest" to justify the burden).

165. See FCC v. League of Women Voters, 468 U.S. 364, 380-81 (1984).

166. Id. at 380 .

167. Id. at 392; see also id. at 395 (discussing less restrictive means of achieving the same objective). 
If the tests are largely indistinguishable as a practical natter, one might reasonably ask why a doctrinal shift to the Central Hudson test is necessary. There are several reasons, foremost among thein the weakness of the "scarcity" rationale on which Red Lion and its progeny uncomfortably rest. ${ }^{168}$ Furtherunore, the current Red Lion regime inadequately protects broadcasters when they do espouse a poitical, philosophical, aesthetic, or similar kind of viewpoint. Indeed, under the Commission's regulations, such programming might trigger a right of reply. ${ }^{169}$ Broadcasters should enjoy the full protection of the First Amendment when they are engaged in non-commercial speech activities.

Even under a unitary theory of the First Amendment, in which the commercial speech doctrine, rather than Red Lion, justifies some government regulation of broadcasting, courts should remain vigilant about attempts to use the regulation of broadcasters as an indirect means of restricting or suppressing disfavored kinds of speech. Although a broadcaster's decision to air a particular show is essentially commercial in nature, the producers of that show probably have a valid claim to full First Amendment protection of their work as non-commercial speech. A regulation that burdens or prohibits a particular kind of show from being broadcast not only impinges on a broadcaster's commercial speech rights, but also affects the non-commercial speech of the program's creators. Government regulations that directly burden the speech rights of those producnig programming should therefore be subject to First Amendment attack on the ground that such regulations have a chilling effect on the burdened speech.

For example, the Commission currently has rules prohibiting the broadcast of "indecent" programming outside certam safe harbor periods, severely restricting the times during which such programming nay be aired. ${ }^{170}$ These restrictions have been up-

168. See supra notes $66-80$ and accompanying text.

169. Although the Commission has abandoned the fairness doctrine, which required stations to provide free airtime wheuever a station aired a position on a controversial issue, it has retained two corollary doctrines: the Personal Attack Rule, 47 C.F.R. $\S$ 73.1920 (1995), and the Pohitical Editorials Rule, 47 C.F.R. $\$ 73.1930$ (1995). If a station airs a personal attack incident to discussion of a controversial issue, it must permit the person attacked to respond. 47 C.F.R. $\$ 73.1920$. Likewise, if a station editorially endorses or opposes a candidate for public office, it must permit other candidates running for the same office or the candidate opposed by the station to respond. 47 C.F.R. $\S 73.1930$.

170. See Hundt, supra note 3 at 1120; see also ACT III, 58 F.3d 654, 656 (D.C. Cir. 1995) (en banc); FCC v. Pacifica Foundation, 438 U.S. 726, 732-33 (1978). 
held under the Red Lion scarcity rationale because "[i]t is the right of the public to receive suitable access to social, political, aesthetic, moral and other ideas and experiences," rather than the broadcaster's interest in editorial freedom, "which is crucial here."171 Thus, under Red Lion, the public's imterest in being free from offensive material outweighs both a broadcaster's interest in disseminating such material, and a producer's or director's interest in creating such materials. ${ }^{172}$

In a post-Red Lion world, the Commission should not be permitted to adopt regulations that directly burden particular types of speech, even if the broadcaster does not select the programming in order to promote a particular political, philosophical, or aesthetic viewpoint. For example, booksellers routimely challenge local regulations that preclude them from selling certain kinds of materials. ${ }^{173}$ Most large commercial booksellers are largely, if not completely, indifferent to the inaterials they sell. If they could achieve the highest possible return by selling ouly Howard Stern's Miss America, they would stock ouly this book. ${ }^{174}$ Yet, federal courts permit them to challenge restrictions on offering particular kinds of material for sale. I submit that a bookseller's success in such a case does not reflect concern for the ability of the bookseller to complete a commercial transaction, but rather for the speecli rights

171. Red Lion, 395 U.S. at 390.

172. Pacifica Foundation, 438 U.S. at 748-49.

173. See, e.g., American Booksellers Ass'n, Inc. v. Hudnut, 771 F.2d 323, 324-25 (7th Cir. 1985), mem. aff'd, 475 U.S. 1001 (1986); see also Virginia v. American Booksellers Ass'n, Inc., 484 U.S. 383 (1988); Bantam Books, Inc. v. Sullivan, 372 U.S. 58 (1963); Butler v. Michigan, 352 U.S. 380 (1957); Graff v. City of Chicago, 986 F.2d 1055 (7th Cir.), rev'd, 9 F.3d 1309 (7th Cir 1993) (en banc), cert. denied, 114 S. Ct. 1837 (1994).

174. There are, of course, booksellers that have particular ideological points of view. For example, the Feminist Attic or Pink Triangle Books probably forgoes opportunities to make sales in order to maintam their ideological purity, i.e., the Feminist Attic probably does not stock Penthouse, and one would likely be hard-pressed to find Anita Bryant's official biography in Pink Triangle Books. Nominally commercial entities eugaged in significant non-commercial speech activity incident to their commercial operations should be permitted to use the First Amendment to protect their ideological mission from governinent regulation, even though this ideology is annexed to a commercial or economic activity. The test should be whether the particular speech activity at issue involves or implicates non-commercial speech activity, given the context in which the speech occurs and the probable intent or motivation of the speaker. See Bolger v. Youngs Drug Prods. Corp., 463 U.S. 60, 66-68 (1983) (relying on context and the speaker's probable motivation to characterize speech as "commercial" or "noncommercial"); see generally Hoffman Estates v. Flipside, Hoffman Estates, Inc., 455 U.S. 489 (1982) (same). 
of those who actually create the materials at issue. If a bookstore cannot sell a particular class of materials (e.g, "indecent" books), the speech rights of those engaged in the creation of works falling within the proscribed class will be substantially burdened, and the prohibition will significantly chill their speech activities. ${ }^{175}$

One could also conceptualize the interest as that of the public in receiving or having access to the materials. ${ }^{176}$ Courts are not acting to protect the booksellers' ability to make profitable salesinstead, they are protecting the derivative speech rights of writers and the general pubhic. Broadcasters should also be permitted to raise the speech rights of those producing particular kinds of programming and those who wish to watch it. ${ }^{17}$

Under a unitary theory of the First Amendment, broadcasters should be free to shock, offend, or alienate their audiences. ${ }^{178}$ Of course, if a broadcaster offends too many viewers too often, it will soon lack an audience, and advertisers will withdraw their support. ${ }^{179}$ The market would thus serve as an effective regulator of the content of broadcast radio and television. ${ }^{180}$ Government

175. The same analysis would apply to most commercial exhibitors of motion pictures. See Freedman v. Maryland, 380 U.S. 51, 57-60 (1965); see also 414 Theater Corp. v. Murphy, 499 F.2d 1155, 1159 (2d Cir. 1974).

176. See Butler v. Michigan, 352 U.S. 380, 381-84 (1957); Graff v. City of Chicago, 986 F.2d 1055, 1061 (7th Cir. 1993), rev'd, 9 F.3d 1309 (7th Cir. 1993) (en banc), cert. denied, 114 S. Ct. 1837 (1994); see generally Virginia State Bd. of Pharmacy v. Virginia Consumer Council, 425 U.S. 748 (1976) (emphasizing society's interest in the free flow of consumer information).

177. See, e.g., Umited States Parole Comm'n v. Geraghty, 445 U.S. 388, 403-07 (1980) (permitting a third party to assert the legal rights of another); Singleton v. Wulff, 428 U.S. 106, 117-18 (1976) (plurahty opinion) (same).

178. Some might suggest that broadcasters are already free to do this. For example, Howard Stern and G. Gordon Liddy appeal to particular segments of the listening public. However, the FCC has assessed significant fines against Stern's syndicator, Infinity Broadcasting. See, e.g., Letter from Williain F. Caton, Acting Secretary, FCC to Mr. Mel Karmazin, President, Infinity Broadcasting (May 20, 1994), reprinted in 9 F.C.C.R. 6442 (1994). These fines represent a disincentive to air Stern's morning show; because the show is wildly profitable, however, Infinity paid the fine and Mr. Stern remains safely ensconced behind his microphone. However, those whose programming does not enjoy the phenomenal popularity of Howard Stern's will find it much harder to get their material broadcast, even if there is a non-trivial audience that wishes to receive such prograwming.

179. See, e.g. KRATTENMAKER \& Powe, supra note 9, at 278-83; Fowler \& Brenner, supra note 32, at 209-10; Network Programming Chiefs Face Viewers for Quality TV, BRoAdCASTING, Oct. 2, 1989, at 49.

180. A number of academics have suggested a "Civic Republican" model for justifying governmeut regulation of broadcasters. See, e.g., SUNSTEIN, supra note 9, at 241-52; Cass R. Sunstein, The First Amendment in Cyberspace, 104 YALE L.J. 1757, 1759-65 (1995). 
would retain the power to regulate television and radio broadcasters' speech in ways consistent with Central Hudson, provided that the regulations would not directly burden a particular category of speech that artists and performers wish to create and the public wishes to receive. ${ }^{181}$ Under this approach, the Com-

Sunstein appears quite willing to trust in the government's ability to make us good citizens. The First Amendment, however, reflects a gamble on the good sense of the population; if we permit broadcasters, publishers, and evil politicians to debase our culture to the point that we are no longer capable of self-governmeut, the experiment obviously will have been a failure. In any event, it requires rather circular logic to argue that the First Amendment exists to facilitate democratic self-government (a proposition with which I agree) and to conclude from this premise that democratically-elected majoritarian bodies should be permitted to enact regulations of speech which they believe will facilitate effective or virtuous self-government. Sunstein, supra, at 1804 ("Instead of allowing new technologies to use democratic processes for their own purposes, constitutional law should be concerned with harnessing those technologies for democratic ends-including the founding aspirations to public deliberation, citizenship, political equality, and even a certam kind of virtue."). A more logical conclusion is that the words of the First Amendment in large part actually mean something fairly close to what they seem to say: Congress may pass "no law . . . abridging the freedom of speech." Sunstem's versiou, by way of contrast, appears to prohibit government froin euacting any "anti-democratic" or "poorly conceived" laws abridging the freedom of speech. I prefer the original text to Sunstem's proposed "new, improved, and updated" version.

Nor do I understand Sunstein's confidence in the ability of government to promote "virtue." Indeed, if history is any guide in matters of this sort, government tends to seek its own perpetuation, and those in office the continuation of their sinecures. See Epstein, supra note 101, at 54. The history of government regulation of speech is particularly telling: From the Alien and Sedition Act of 1789, to the persecution of presumed communists in the 1950s, government has shown an uncanny knack for squelching speech that it deems inimical to its well-being and comfort. In light of this track record, we should view with great skepticisin suggestions that the government be empowered to enact laws that will make us good. As Professor Owen Fiss has observed, "[t] he state has no corner on virtue." Fiss, supra note 16, at 789. In consequence, there is no reason to believe that those persons we elect to public office possess any greater perspicacity than we ourselves do in deciding questions of virtue and morality. See generally William J. Brennan, Jr., The Supreme Court and the Meiklejohn Interpretation of the First Amendment, 79 HARV. L. REV. 1, 11-16 (1965).

181. For example, PBS sponsored the production of Armistead Maupin's Tales of the City, which aired nationally on local PBS affiliates. The program featured drug use, nudity, and provided overt examples of gay and lesbian affection. Notwithstanding its treatment of controversial subjects, it is undoubtedly one of the best made-for-television series in recent meinory; "Tales of the City" was intelligent, challenging, and entertaining fare for adults. It was also, at least arguably, "indeceut," and a number of affiliates objected to airing it. See, e.g., John Carman, New PBS Chief Says Maupin Should Be Grateful, Not Upset, S.F. CHRON., July 28, 1994, at A1 (reporting problems associated with airing the series because of content); Betsy Sharkey, Maupin's Dream of the Future, Set in the Past, N.Y. TMMES, Feb. 28, 1993, \& 2, at 27 (reporting difficulties with producing Tales of the City because of its content). The adult audience cannot expect to enjoy much access to programming fare of this quality under the current command and control regime. 
mission would continue to possess broad discretion to promote the "public interest, convenience, and necessity."182

This jurisprudential shift likely would have the salutary effect of strengthening the commercial speech doctrine. By expanding the scope of the doctrine's application, the federal courts probably would apply the doctrine inore aggressively. Relatedly, there is little reason to believe that shifting from Red Lion to Central Hudson would decrease broadcasters' net speecli rights in any ineaningful way. Indeed, parties bringing commercial speech claims before the Supreme Court have enjoyed considerable success. ${ }^{183}$ This has not always been the case for those with non-commercial speech claims. ${ }^{184}$ Finally, the shift in paradigm would free public broadcasters and those commercial broadcasters who are routinely engaged in non-commercial speech froin burdensoine regulation. Public broadcasters are not "commercial" in any meaningful sense, and therefore would be able to claim the full benefit of the First Amendment. ${ }^{185}$ Commercial broadcasters who engage in noncommercial speech activity also could claim such benefits. ${ }^{186}$

182. 47 U.S.C. $\S 309$ (a) (1988). For example, the rules governing political candidates' right of "reasonable access" to advertising time on commercial television and radio stations would remain constitutional. See 47 C.F.R. $\S 73.1944$ (1995). By definition, these regulations pertain to commercial speech-broadcasters generally sell their advertising time to the highest bidder, through the nse of an auction-based preemption scheme. Likewise, Commission efforts to diversify the content of programming by encouraging broadcasters to air particular kinds of programming would also pass muster, because such rules do not generally impose any direct burden on other speakers or the public. Other kinds of "thou slialt" rules that do not directly burden particular kinds of speech would also be permissible (e.g., broadcasters' obligation to produce local programming on politics and community affairs).

183. Indeed, with the notable exceptions of Posadas and Edge Broadcasting, the Supreme Court has routinely vindicated the speecl claims of those with "commercial" speech cases. See Rubin v. Coors Brewing Co., 115 S. Ct. 1585, 1594 (1995); Cincinnati v. Discovery Network, Inc., 507 U.S. 410, 430-31 (1993); Bolger v. Youngs Drug Prods. Corp., 463 U.S. 60, 75 (1983); Bigelow v. Virginia, 421 U.S. 809, 818-29 (1975); see also Rodney A. Sinolla, Information, Imagery, and the First Amendment: $A$ Case for Expansive Protection of Commercial Speech, 71 TEX. L. REV. 777, 791 n.58 (1993).

184. See, e.g., International Soc'y for Krishna Consciousness v. Lee, 505 U.S. 672, 685 (1992); Barnes v. Glen Theatre, Inc., 501 U.S. 560, 562-72 (1991); United States v. Kokinda, 497 U.S. 720, 737 (1990); Cornelins v. NAACP Legal Defense \& Educ. Fund, 473 U.S. 788, 813 (1985); City Council of Los Angeles v. Taxpayers for Vincent, 466 U.S. $789,803-17$ (1984).

185. Cf. FCC v. Pacifica Foundation, 438 U.S. 726, 741, 741 n.17 (1978) (upholding government regulation of a non-commercial radio station's programming content); Alliance for Community Media v. FCC, 56 F.3d 105, 122 (D.C. Cir. 1995) (en banc) (upholding government regulation of non-commercial cable stations' programming content).

186. For example, a commercial television station dedicated to broadcasting French 


\section{The Chairman's Proposals Should Be Deemed Constitutional}

A unitary, market-based approach to evaluating the First Amendment claims of broadcasters would not preclude the Commission from adopting its proposed children's educational programming rules. Contrary to the suggestions of some commentators, ${ }^{187}$ there still would be an active role for the Commission to play under such a constitutional regime.

Government is free to regulate commercial speech in order to achieve "substantial" public policy objectives. Furtliermore, such regulations need not directly burden those producing particular kinds of programming, nor the ability of the viewing public to see such programming. ${ }^{188}$ The Commission should be free to adopt viewpoint-neutral but content-sensitive regulations that chamel or restrict commercial television broadcasters' programming decisions, provided the regulations serve substantial public pohicies. ${ }^{189}$ Confronted with such regulations, broadcasters would find it difficult to provide any non-commercial rationale for the selection of most, if not all, of their children's programming. ${ }^{190}$ Accordingly, the proposed children's programming rules should be deemed a regulation of "commercial" speech. ${ }^{191}$

language programming would enjoy enhanced speech rights, at least insofar as its claim to being free from regulation relates to its decision to promote the use of French.

187. See, e.g., Statement of Professor Rodney A. Smolla, supra note 46, at 6-26 (arguing that the "proposed processing guidelines, programming standards, and definitions of core educational programming violate the First Amendment").

188. Stated differently, the government's decision to encourage or facilitate a particular kind of speech activity should not be deemed a burden on all other kinds of speech activities. See Rust v. Sullivan, 500 U.S. 173, 192-200 (1991). Similarly, a content-sensitive regulation of speech is not the same thing as a viewpoint-discriminatory regulation of speech. See SUNSTEIN, supra note 9, at 11-14, 168-171.

189. "With respect to noncommercial speech, this Court has sustained content-based restrictions only in the most extraordinary circumstances. . . By contrast, regulation of commercial speech based on content is less problematic." Bolger v. Youngs Drug Prods. Corp., 463 U.S. 60, 65 (1983).

190. Capital Cities/ABC's decision to drop "CRO" in favor of "Dumb and Dumber" ouce again provides an instructive example. See generally MiNOW \& LAMAY, supra note 2 , at 10-11, 19-21 (discussing the CTA and the use of children as markets for commercial gain).

191. Indeed, at least with respect to children's programming, there is sometimes a direct tie-m between programming and a particular line of products. See, e.g., Littleton, Kids-Show Rush for Fall, BROADCASTING \& CABLE, Jan. 1, 1996, at 26-27 (describing "Pillow People," a show based "on a line of bed sheets and home furnishings"); see generally MNOW \& LAMAY, supra note 2, at 45-46, 52-57 (discussing the dramatic change in children's programming following the deregulation of commercial time limits); 
It is also important to note that under the proposed regulations, the only burdened party is the broadcaster, who must provide "children's educational programming," rather than some other type of programming. As mentioned above, broadcasters' First Amendment claims against regulations that only imdirectly burden particular kinds of programming are significantly less compelling than complaints about programming rules that directly burden particular types of programming. This is so because of the impact that direct burdens have on the production of programming and on the ability of the public to receive such programming. Given that the proposed educational children's programming regulations do not directly burden other kinds of programming, broadcasters would be hard-pressed to argue persuasively that the proposed rules will have a chilling effect on the speech rights of others, or that the rule will deny the viewing public access to a particular category of programming. ${ }^{192}$

It therefore seems appropriate to rely on Central Hudson to evaluate the legality of the proposal. ${ }^{193}$ Under Central Hudson, the government is free to regulate commercial speech if the regulation furthers a substantial government interest, is narrowly tai-

Charren, supra note 96, at 1252-55 (discussing the increasing use of program-length commercials disguised as children's television).

192. In his statement in support of the NAB's comments, Professor Sinolla argues quite vigorously that the government cannot coerce speech, and that the proposed regulations would do just that. See Statement of Professor Rodney A. Sinolla, supra note 46, at 6-10. This is certainly true as a general proposition. However, the federal courts have sustained regulations that coerce or compel broadcasters' speech; under Red Lion, commercial television broadcasters are subject to mandatory forms of speech that could not be imposed on newspapers or individual citizens. For example, broadcasters must identify program sponsors, and must do so in specific ways. See 47 C.F.R. \& 73.1212; 47 U.S.C. $\S$ 317 (1994) (requiring announcement of payment for broadcast); cf. McIntyre v. Ohio Elections Comm'n, 115 S. Ct. 1511 (1995) (holding that a private citizen need not identify herself as the author of a political tract). They inust also air political advertisements for federal candidates, even if the content of these advertisements violates their usual editorial standards. See 47 U.S.C. \& 315 (1994); 47 C.F.R. § 73.1944 (1995); Gillett Communications of Atlanta, Inc., v. Becker, 807 F. Supp. 757 (N.D. Ga. 1992) (holding that broadcasting indecent material is not subject to requirements of reasonable access and no censorship), affd, 5 F.3d 150 (11th Cir. 1993). Finally, the government has mandated warning statements for advertisements touting tobacco products-a form of affirmativcly coinpelled speech that the federal courts have approved. See 15 U.S.C. $\S \S 1331,1333$, 1335 (1994); Capital Broadcasting v. Mitchell, 333 F. Supp. 582, 588 (D.D.C. 1971). The proposition that the Congress and the Commission are constitutionally limited to promulgating only negative rules regulating broadcasters' speeclt is therefore open to question, at least so long as Red Lion remains good law.

193. See supra notes $93-98,148-59$ and accompanying text. 
lored, and directly furthers the interest asserted. ${ }^{194}$ The Chairman's proposals satisfy Central Hudson's requirements.

Ensuring that America's children have access to meaningful educational programming is a substantial government interest. ${ }^{195}$ "[T] [has] justified the regulation of otherwise protected expression., 196 Indeed, this interest might even be deenned "compelling."197 The regulation is narrowly tailored-m its strongest form, it would require commercial television broadcasters to air no less than three hours per week of educational children's programming and no more than five hours per week between the hours of 6 a.m. and 10 p.in. In this time period, broadcasters have over 105 hours to program during a seven day week; the government would at most structure broadcasters' editorial decisions over $5 \%$ of their total available time. Commercial broadcasters would remain free to program the remaining time slots--representing over $95 \%$ of the time available in this portion of the broadcast day-as they think best.

Furthermore, commercial broadcasters claim that they presently provide over four hours per week of children's educational programming. ${ }^{198}$ If this is true, the proposed regulation would at most require soine broadcasters to modify the kind of children's programming that they provide to satisfy the Commission's criteria for "educational" programming. ${ }^{199}$ In addition, the proposed regulations would leave broadcasters free to select whatever programming they think best-the proposals are content-neutral, at least if

194. Central Hudson, 447 U.S. at 563-66.

195. See FCC v. Pacifica Found., 438 U.S. 726, 749 (1978); Ginsberg v. New York, 390 U.S. 629, 639-40 (1968); see also Comments of the United States Catholic Conference, In re Policies and Rules Concerning National Children's Television Programming, MM Docket No. 93-48, at 2-4 (FCC Oct. 16, 1995).

196. Pacifica, 438 U.S. at 749 (quoting Ginsberg v. New York, 390 U.S. 629, 639 (1968)).

197. See Note, See No Evil, Hear No Evil: Television Violence and the First Amendment, 81 VA. L. REV. 175, 209-11 (1995); see also MiNow \& LAMAY, supra note 2, at 175. For a description of the importance of educational children's programming, see Comments of the Center for Media Education et al., supra note 84, at 20 \& n. 60 .

198. See Comments of the NAB, supra note 24, at 2-4,6, attachment 1 (asserting that in 1991 and 1992, broadcasters aired 3.6 lours per week of children's educational programming).

199. See supra note 21. 
judged by the Turner Broadcasting Court's definition of the term. ${ }^{200}$

There can be little doubt that the regulations would increase the quality and quantity of educational children's programming. Although there is reason to doubt the overall impact of the proposed reforms, ${ }^{201}$ the regulations would sufficiently advance the government's interest in securing an adequate amount of educational children's programming to satisfy Central Hudson. ${ }^{202}$ Accordingly, there is no serious First Amendment objection to their proinulgation. ${ }^{203}$

III. WILlIE WONKA AND THE POLICY FACTORY: WILL ChaIRMan HundT'S PROPOSAIS ACTUALly HElP ChILDREN?

In Part I, I argued that two simple questions need to be answered before one can reacll a conclusion regarding the inerits of Cliairman Hundt's proposals to improve the quantity and quality of children's educational programming. The first-whetler the proposals are lawful-has been answered affirmatively. I now proceed to the second question, whicl takes up the probable efficacy of the Chairman's reforms. In this regard, two separate pohicy issues must be analyzed. First, is there really a problein that the Coinmission needs to address? Second, assuming that some sort of regulatory action is needed, are the Chairman's proposals the best response to the problein identified? For a bad regulatory response can often be worse than no response at all. ${ }^{204}$

200. See Turner Broadcasting Sys., Inc. v. FCC, 114 S. Ct. 2445, 2460-61 (1994). The Commission's proposed regulations direct broadcasters to show three hours of educational children's programming without mandating that any particular viewpoint be advanced or that any particular subject be canvassed in the children's programming. This approach seems to pass Tumer's test. See id.

201. See infra notes 216-229 and accompanying text.

202. Cf. City of Cincinnati v. Discovery Networks, Inc., 507 U.S. 410 (1993).

203. As noted above, the Red Lion/League of Women Voter's test for regulations that restrict the speech rights of broadcasters is virtually identical to the Central Hudson test for commercial speech. Red Lion, 395 U.S. at 390 . Thus, even if one were to reject my suggestion that Red Lion be abandoned in favor of a unitary model of the First Amendment, the same conclusion would obtain, i.e., the proposed regulations are constitutional under Red Lion and League of Women Voters.

204. Regulators would do well to observe the Hippocratic oath's admomition that first and foreinost, they must "do no harm." See Louis L. Jaffe, James Landis and the Administrative Process, 78 HARv. L. REv. 319, 320 (1964). 


\section{A. Jack and the Beanstalk: Magic Beans and Market Failure}

As we all know, Jack traded the family's beloved cow for a handful of "magic" beans. The results were mixed; Jack obtained rents through the felonious reallocation of a certain giant's chattels, but the result was not an entirely happy one. All in all, Jack's family would probably have been better off keeping the cow.

One could analogize the cow to reliance on the market, and the magic beans to regulatory command and control initiatives. Good arguments can be made in favor of relying, to the maximum extent possible, on market-based solutions to the provision of children's programming. Perhaps most significantly, reliance on the market is efficient. ${ }^{205}$ The market puts goods and services together with willing purchasers with lower transaction costs than the government's command and control efforts.

However, Cliairman Hundt claims that the market has failed to provide a satisfactory anount of educational children's programming. ${ }^{206} \mathrm{He}$ asserts that incident to the Commission's broad residual powers to manage the electromagnetic spectrum in a fashion consistent with the public interest, it could inipose command and control regulations on broadcasters to remedy the perceived market failure. ${ }^{207}$ In the Chairman's view, the Commission is not legally required to defer to the market. ${ }^{208}$

205. See Ferris \& Leahy, supra note 47 , at 321-22 ("The marketplace approach to broadcast regulation springs from the view that consumers are best off when society's resources are allocated in a manner that permits them to seek their own wants and desires as fully as possible ...."); Fowler \& Brenner, supra note 32, at 210-13, 230-31 (explaining that "consumers are best off when society's economic resources are allocated in a manner that enables people to satisfy their wants as fully as possible," and arguing that rehance on the marketplace best facilitates this result); HENRY GELLER \& DONNA LAMPERT, ChARgING FOR SPECTRUM USE 11-17, 16 (1989) (explaining that a spectrum fee "achieve[s] pubhic interest objectives more directly than by the indirect and ineffective methods of the present pubhic trustee scheme"); see also Coase, supra note 76, at 16-20.

206. See Chairman Reed E. Hundt, Reading the First Amendment in Favor of Children, Address to the Faculty and Students of Brooklyn Law School, 1-3, 6-7 (Dec. 4, 1995) (transcript on file with author); Chairman Reed E. Hundt, Long Live Frieda Hennock, Address to Women in Government Relations, 6-7 (Aug. 24, 1995) (transcript on file with author).

207. See 47 U.S.C. $\S 303(a)$, (b) (granting broad powers to the SEC).

208. See Hundt, supra note 3 , at 1091 . Unsurprismgly, the coininercial broadcasters believe that continued rehance on the market will resolve the problem. See Comments of the NAB, supra note 24, at 8-13. In fact, the light at the end of the tunnel appears to have always been in sight. In 1980 , broadcasters told the Commission that "responsible self-regulation and rehance upon marketplace forces are the most effective means of meeting their obligation to the child audience." Children's Programming and Advertising 
At the outset, it bears noting that the legislative history of the Children's Television Act specifically rejects continued rehiance on the market as an acceptable means of securing an adequate amount of educational children's programming. ${ }^{209}$ Accordingly, Chairman Hundt's claim that the Commission cannot rely solely on market forces to provide the desired goods seems legitimate-if not compelled. Moreover, he is also correct in positing that the narket has done a relatively poor job of providing educational children's programming. ${ }^{210}$ The market often fails to provide socalled "public goods," because the true demand for such goods is often difficult to measure. ${ }^{211}$ Moreover, markets often act in a reactive, ratlier than a proactive, fashion. As Professor Owen Fiss has observed, "[a] fully competitive inarket imight produce a diversity of programs, formats, and reportage, but ... it will be the diversity of 'a pack going essentially in one direction." "212

The work of Dr. Dale Kunkel persuasively demonstrates that commercial television broadcasters are not meeting the educational programming needs of children. ${ }^{213}$ His work establishes that, ab-

Practices, supra note 43 , at 638 . ABC claimed that "the steady progress of marketplace changes [will] continue to enhance the overall diversity and availability of children's programming." Id.

209. See also H.R. Rep. No. 385, 101st Cong., 2d Sess. 5-8 (1990), reprinted in 1990 U.S.C.C.A.N. 1605, 1609-12; S. Rep. No. 66, 101st Cong., 2d Sess. 1-13 (1990), reprinted in 1990 U.S.C.C.A.N. 1628, 1628-40.

210. Of course, there are a number of probable reasons for this state of affairs. Educational programming must produce lower rents for broadcasters than programming designed to entertain children. This may be because advertisers beheve that more children will watch entertaining programs, or because it is more expensive to produce educational children's programming, or the cause may involve both reasons. Perhaps the most likely rationale is that producing high-quality educational children's programming is more timeconsuming, requires expertise not generally available, and has a smaller market. See MINOW \& LAMAY, supra note 2, at 36-52. Thus, high quality educational programming is scarcer and therefore more expensive than the standard schlock programming that fills most early Saturday morning time slots. Although an ample supply of low quality educational children's programming is probably available, such shows are imlikely to generate significant audiences. Accordingly, advertisers will not purchase advertising slots for these shows, and broadcasters will have no incentive to show them.

211. See KRATTENMAKER \& POWE, supra note 9, at 40-43; SUNSTEIN, supra note 9, at 68-71; Ferris \& Leahy, supra note 47 , at 323-24.

212. Fiss, supra note 16, at 787 (citation omitted); see also NoLL ET AL, supra note 84, at 211-17 (explaining the economic and policy rationales for public television). But see Stephen F. Williams, Background Norms in the Regulatory State, 58 U. CHI. L. REV. 419, 427-28 (1991) (arguing that ostensible "public goods" are really the aesthetic preferences of paternalistic elites).

213. See Comments of Dr. Dale Kunkel, supra note 17; Reply Comments of Dr. Dale Kunkel, supra note 23; Broadcaster's License, supra note 17; Kunkel \& Goette, supra 
sent regulation, broadcasters seek to maximize rents by airing inexpensive cartoons featuring violence and mayhem, or simply declare entertainment programming, such as "America's Funniest Home Videos," to be "educational children's programming."214 Left to their own devices, it appears highly unlikely that commercial television broadcasters will change their ways.

A government mandate might successfully provide imcentives to both program producers and commercial television broadcasters to develop more and better educational children's programming. With respect to the Chairman's proposals, "[t]he purpose of the state is not to supplant the market (as it would under a socialist theory), nor to perfect the market (as it would under a theory of market failure), but rather to supplement it."215

In short, there is a market-based problem in need of a regulatory solution. The question, then, is whether Chairman Hundt's proposals represent the best response to the shortcomings of the inarket.

\section{B. Hansel and Gretel: Substituting Brussels Sprouts for the Ginger- bread House?}

Hansel and Gretel were two typical kids. Presented with a gingerbread house accented with assorted sweets, they responded with alacrity to the prospect of adopting a diet of bon bons, gingerbread, and assorted candies. ${ }^{216}$ Of course, partaking of the gingerbread house came with a non-trivial opportunity cost (that is, being eaten by the witch). Had the witch atteinpted to ply Hansel and Gretel with a house made of tofu, roofed with leafy greens, and covered with brussels sprouts, carrots, and other

note 17.

214. Comments of Dr. Dale Kunkel, supra note 17, at 1-2; see also Joint Comments of the Association of America's Public Television Stations and the Public Broadcasting Service, In re Policies and Rules Concerning Children's Television Programming, MM Docket No. 93-48, at 5-9 (FCC Oct. 16, 1995) [hereinafter Joint Comments of APTS/PBS] (describing the high cost of producing high quality children's television).

215. Fiss, supra note 16, at 788; see also Ferris \& Leahy, supra note 47 , at 322 ("Markets, however, do not offer a talismanic solution to the problems of broadcast regulation.").

216. Their belravior was not at all surprising; every Halloween children exhibit the same sort of behavior, greedily scarfing down their hard-won loot, the consequences be damned. 
"healthy" foods, it is rather doubtful that the children would have taken the bait-the attraction just would not have been the same.

Too much of today's children's programming is similar to the witch's gingerbread house: irresistible to kids, but of dubious value. That said, one cannot deny the inherent attraction that shows hike "Power Rangers" and "The Mask" hold for young viewers (if not their parents). Moreover, children sometimes respond to "educational" shows in much the same way that they respond to "healthy" foods-they attempt to avoid them. ${ }^{217}$ To overcome this natural aversion, programmers must dream up creative and entertaming ways of getting and keeping children's attention. Given this state of affairs, one needs to question whether mandated educational children's programming will hold the same attraction for young viewers as the current crop of entertaining, but unenlightening, children's programs.

Even if the Commission can lawfully mandate quantitative and qualitative standards for educational children's programming-and assuming that the market has failed to meet the nation's need for this sort of programming-it is unclear whether, as a practical matter, the proposed regulations will achieve their desired objective effectively. ${ }^{218}$ Legality coupled with the need for government action does not mean that a particular policy actnally will work. At this level, rather than at the constitutional level, Cliairman Hundt's reform proposals may be misguided. Obviously, if the Commission mandates qualitative and quantitative standards for children's educational programming, broadcasters will have to comply. In the strictest sense, the proposals caimot fail. However, for a variety of reasons, I am not sure that the Chairman's proposals will succeed in a larger sense.

Meaningful success implies that broadcasters air programming that children actually watch. If forced to air educational children's programming, commercial television broadcasters face two choices: They can attempt to produce and air high quality children's programming that will draw significant advertiser support, or they can

217. See Comments of Capital Cities/ABC, supra note 24, at 16; see also Comments of the Walt Disney Co., In re Policies and Rules Concerning Children's Programming, MM Docket No. 93-48, at 4-10 (FCC May 7, 1993).

218. For a listory of the Commission's efforts at improving the quantity and quality of educational children's programming, see Winer, supra note 69, at 278-82. 
seek out inexpensive, low quality educational programming and air it during their least profitable time slots. ${ }^{219}$

If producing and airing high quality educational children's programming were profitable, broadcasters already would doing so. Indeed, at a speecl last summer to the National Press Club, Cluairman Hundt admitted that broadcasting educational children's programming is not a profitable activity for most commercial broadcasters, or is, at the very least, significantly less profitable than airing other kinds of programming. ${ }^{220}$ The current proposals will not affect this economic fact-a state of affairs that the Cluairinan lias acknowledged. ${ }^{221}$

Replacing entertaining children's programming with educational programming of low quality will not materially advance the interests of children, parents, or the nation as a whole. ${ }^{222}$ For the last forty years, the Commission's efforts to improve the anount and quality of children's programming have not been particularly successful. ${ }^{223}$ There is little reason to believe that the current initiative will be meaningfully different in its ultimate effects, notwitlustanding Claairnan Hundt's best efforts and his unquestionably laudable objectives.

Furthermore, even if the Chairnan's proposals are effective, and broadcasters do produce and air high quality children's programming, unless doing so becoines more profitable than airing alternative programming, they will likely revert to their old ways

219. Those who saw the movie "Mrs. Doubtfire" may recall the science show that Mrs. Doubtfire's show replaced. It featured an ancient academic, seated behind a metal desk, droning on in a monotone about the history of dinosaurs. I fear that the Commission's proposal may prove to be an unintended windfall for the producers, directors, and cast members of such shows. See MiNow \& LAMAY, supra note 2, at 57. They are inexpensive to produce and would satisfy the "core" programming requirements of the Chairman's proposal.

220. Chairman Reed E. Hundt, Address to the National Press Club 3-8 (July 27, 1995) [hereinafter Press Club Speech]; Joint Comments of APTS/PBS, supra note 214, at 4-9; Comments of the Center for Media Education et al., supra note 84, at 6; see also Entman, supra note 25, at 78 ("[T]he pohicy of deregulation, by exposing media owners to the full force of market competition and consumer demand, greatly affects the ideas that [commercial] broadcasters can practically choose to produce and distribute if they want to stay in business.").

221. Press Club Speech, supra note 220, at 6-8; see also NOLL ET AL, supra note 84, at 12 (notimg that public interest programming "account[s] for less than 5 percent of network prime time simply because [it is] not as profitable as light entertainment").

222. See Children's Programming and Advertising Practices, supra note 43, at 653-54; see also MINOW \& LAMAY, supra note 2, at 57.

223. See Press Club Speech, supra note 220, at 6-7. 
as soon as a new chairman is in place. The Commission's staff, although professional, is sensitive to the priorities of the Chairman's office. The sad truth is that in terms of compliance with the proposed reforms, the Commission must expect broadcasters to do the least amount necessary to comply for the shortest period of time. ${ }^{224}$

If short-term compliance were likely to lead to fundamental clianges in advertiser support patterns, there might be some cause for optimism. ${ }^{225}$ However, the current paucity of educational programming must reflect higher opportunity costs associated with the production of sucli programming. It is easier to produce and market "The Itchy and Scratcliy Show" successfully than to make and sell "Bill Nye-The Science Guy."226 Because creating and producing entertaining educational children's programming is harder than seeking inerely to entertam through mindless violence, it seems probable that it will always be more profitable to produce and air non-educational children's programming. ${ }^{227}$

In addition, the market for advertising time in children's programming is obviously more slallow than for more generic fare. ${ }^{228}$ Six-year-olds do not buy Lexus luxury sedans. ${ }^{229}$ The universe of potential advertisers is necessarily sinaller for children's programming. This too works as a serious disincentive to air more (or better) children's programming.

Cliairman Hundt's reforms will do no harm. However, there is reason to question whether they will do mucl good in the long

224. See Comments of the Center for Media Education, supra note 84, at 4-6, 10-13, 15-17; Joint Comments of APTS/PBS, supra note 214, at 4-9; see also McConnell, supra note 29 , at 18,22 (reporting on commercial broadcasters' reluctance to air educational children's programming).

225. For instance, if the ratings for these shows were comparable to, or higher than, the ratings for other kinds of children's programming, advertisers nnight begin supporting such programming.

226. Again, the Chairman appears to be well aware of the Commission's "long and undistinguished history of failing to apply responsibly its mandate to make sure broadcasters use the airwaves to serve the pubhic, and specifically, to guarantee that television helps educate our children." Hundt, Long Live Frieda Hennock, supra note 206, at 2.

227. See Joint Comments of APTS/PBS, supra note 214, at 5-10.

228. See Children's Television Programming and Advertising Practices, supra note 43, at 144-46; see also WINER, supra note 69, at 281.

229. See Children's Programming and Advertising Practices, supra note 43, at 639; Fowler \& Brenner, supra note 32, at 253-54; see also KRATTENMAKER \& POWE, supra note 9, at 82-83; MINOW \& LAMAY, supra note 2, at 202-03; SUNSTEIN, supra note 9, at 65-66. 
term. You can lead a horse to water, but you cannot make it drink. As hard as the Commission tries to force commercial broadcasters to fulfill their legal and moral responsibilities to their youngest viewers, it remains doubtful that the commercial television broadcasters will significantly improve the quality of the service they provide to the nation's children. ${ }^{230}$

Even if direct command and control measures of the sort Chairman Hundt has proposed are unlikely to succeed in a larger sense, other regulatory options exist, and deserve the Commission's careful consideration. Were the Commission writing upon a blank slate, perhaps the best solution to the problein of providing access to educational children's programming would be to charge commercial broadcasters some sort of spectrum royalty. The monies generated from this fee then could be used to subsidize directly those entities that actually wish to produce and air high quality educational programming for children. ${ }^{231}$ In fact, a number of commentators have offered proposals under which broadcasters would pay some sort of spectrum fee in lieu of performing soine (or perhaps all) of their traditional "public interest" duties. ${ }^{232}$

Broadcasters would pay a fee to avoid responsibility for providing educational children's programming. The revenues generated from this fee then could be used to support the efforts of the nation's public broadcasters - the ouly broadcasters who have shown a consistent interest in creating and airing high quality children's educational programming - to provide such programming. ${ }^{233}$ Such an approach would provide more children's pro-

230. Indeed, the commercial broadcasters' fierce opposition to Chairman Hundt's modest proposals bespeaks a strong hostikty toward quantitative and qualitative standards for educational children's programming, and bodes ill for future comphance efforts if the Commission ultimately adopts such standards. See Reply Comments of the NAB, supra note 23 , at $2-4,6-8$.

231. See GeLLER \& LAMPERT, supra note 205, at 11-17; Fowler \& Brenner, supra note 32, at 247-55; see also Joimt Comments of APTS/PBS, supra note 214, at 9-19; MINOW \& LAMAY, supra note 2, at 157-61.

232. See GELlER \& LAMPERT, supra note 205, at 12-21; Fowler \& Brenner, supra note 32, at 247-55; see also MINow \& LAMAY, supra note 2, at 157-61.

233. See MiNow, supra note 42, at 43-45; SUNSTEIN, supra note 9, at 84; see also NOLI ET AL, supra note 84, at 241 ("Programming that is regarded as serving a national purpose, such as children's programs, should be directly financed and made available at no cost [on] public TV stations."). The Corporation for Public Broadcasting and the public broadcasting stations across this nation bear the yeoman's burden of providing educational children's programming, a fact that the Commission itself acknowledged in 1983. See Children's Programming and Advertising Practices, supra note 43, at 645. Only 
gramming, more efficiently, than the command and control approach advocated by Chairman Hundt. ${ }^{234}$ A system of spectrum royalties would free broadcasters from undertaking a task for which they obviously have very hittle interest. At the same time, it would guarantee a steady supply of high quality educational children's programming.

But pohtics is the art of the possible, and a spectruin fee approach would probably require congressional authorization. Given the current political climate, it is doubtful that such authorization could be obtamed. In the meantime, children will continue to enjoy a steady diet of "Muppet Babies" and "Power Rangers." Fashioning a sound public policy under these circumstances may therefore require continued reliance on the clunky command and control model, because it is the only option immediately available to the Commission.

The Commission also should consider adopting an approach that places greater direct reliance on America's public television stations. To be sure, conteinporary political developments augur strongly against any sort of renewed political commitment to improving the nation's public television service-at least at the congressional level. ${ }^{235}$ Notwithstanding Congress' lack of commitment to maintaining the nation's public television service, ${ }^{236}$ the Com-

public broadcasting stations provide "Mr. Rogers," "Sesame Street," and "Electric Company"; moreover, they also provide programming that enriches the curriculum of many public schools, including materials on math, the sciences, geography, and foreign languages. Significantly, the NAB las urged greater support of public broadcasting as a potential response to the perceived shortage of children's educational programming. See Comments of the NAB, supra note 23; see also MiNow, supra note 42, at 101; Smolla, supra note 183 , at $24-25$.

234. Indeed, public television stations are virtually the only stations that provide regularly scheduled children's programming in the early inorning and late afternoon lours. Commercial broadcasters liave reserved these time periods-the time periods in which most children are apt to be watching television-for news programming, talk shows, and syndicated re-runs of former prime-time slows. See Joint Comments of APTS/PBS, supra note 214, at 2-4; MINOW, supra note 42, at 37-39. It is more profitable for them to air this programming than an equivalent of Sesame Street. See MiNow, supra note 42, at 4-8.

235. In the current session of Congress, Speaker of the House Newt Gingrich lias repeatedly called for the complete abolition of the Corporation for Public Broadcasting. Warren Berger, We Interrupt this Program . . Forever?, N.Y. TIMES, Jan. 29, 1995, § 2, 1; Ton Shales, The Misguided Missile Aimed at Public TV, WASH. Post, Feb. 27, 1995, at \$ B, 1; Staff Editorial, Public Broadcasting, Public Funds, WASH. POST, Jan. 19, 1995, $\S \mathrm{A}, 24$. He has also advocated the sale by auction of the spectrum public television stations use to broadcast their programming, arguing that cable now offers viewers sufficient programming diversity.

236. Initiatives aimed at eliminating the public broadcasting system are terribly slort- 
mission could, with the help of the commercial broadcasting community, adopt and implement a program that would create strong incentives for the private sector to commit new resources to public television in general and educational children's programming im particular-without resort to new legislation. The Commission's current proposal suggests that broadcasters be permitted to satisfy their educational children's programming requirement at least in part by sponsoring such programming on other stations. ${ }^{237}$ This proposal could be revised to encourage partnerships between local pubhic broadcasters and local commercial broadcasters. If commercial broadcasters prefer to show "Sally Jesse Rafael" and "Geraldo," they should be permitted to do so, provided that parents and children have access to educational programming through public television. ${ }^{238}$ Of course, broadcasters cannot be released coinpletely froin any obligation to provide educational children's programming; as the Commission has noted, the Children's Television Act presupposes that every hicensee should air some educational children's programming. ${ }^{239}$ Rather than releasing commercial television broadcasters from their responsibilities under the Act, this proposal would merely provide them with greater flexibility in meeting their obligations to the nation's youth. ${ }^{240}$

Public television broadcasters have the technical expertise to produce educational programming, and possess a genuine desire to

\footnotetext{
sighted; our country would be immeasurably poorer if we were to lose our public television broadcasting service. Although by 1993 cable passed by $92.9 \%$ of the nation's households, only $61.79 \%$ of the homes passed actually subscribed to cable programming. See In re Implementation of $\S 19$ of the Cable Television Consumer Protection and Competition Act of 1992, 9 F.C.C.R. 7442, 7566 (1994). Given that just under $40 \%$ of our nation's households do not lave cable, sole reliance on cable clrannels to provide educational children's programming seems misguided. In fact, it seems quite likely that the households most in need of access to educational programming-those in poor urban and rural areas-would be the least likely to have the financial wherewithal to subscribe to cable services and that children in these households would therefore be demed the advantages associated with television viewing. See generally Comments of the Children's Defense Fund/Black Commumity Crusade for Children, In re Pohicies and Rules Concerning Children's Television Programming, MM Docket No. 93-48, at 3-5 (FCC Oct. 16, 1995).

237. See Ongoing Children's TV Proceedings, supra note 19, at 6346-48.

238. See generally NOLL ET AL, supra note 84, at 211-29.

239. See Ongoing Children's TV Proceedings, supra note 19, at 6348; but see Comments of the United Church of Christ, supra note 23, at 2-11 (arguing that the Commission's sponsorship proposal would further marginalize educational children's programming).
}

240. See Minow \& LAMAY, supra note 2, at 202-03. 
educate the nation's children through their programming. ${ }^{241}$ Moreover, because public broadcasters are not subject to the economic pressures that commercial broadcasters face, they are far more free to pursue public goods through their broadcasting schedule. ${ }^{242}$ A regulatory response that relies on these strengths seems more likely to be effective. ${ }^{243}$

Commercial broadcasters have empliasized the importance of public broadcasters in meeting the programming needs of children. ${ }^{24}$ It is time for them to do more than clap politely from the sidelines. Moreover, there is a strong consensus within the academic community that public broadcasting loolds the key to ensuring that parents and children liave access to educational children's programming. ${ }^{245}$ Rather than ignore public television's role, the Commission should fashion policies that encourage commercial broadcasters to support public television's efforts to meet the educational programming needs of children, througli direct sponsorship of such programming and by providing public broadcasters witlı $\mathrm{m}$-kind services and technical support. ${ }^{246}$

\section{CONCLUSION}

Children's educational programming is something that everyone nommally supports-no one believes it is sometlimg that we can do without as a nation. Furtliermore, the market plainly lias failed to provide such programming on a consistent basis, at least insofar as commercial broadcasters are concerned. Cliairman

241. See Joint Comments of APTS/PBS, supra note 214, at 2-4, 9-19.

242. Chairman Hundt himself has recognized that commercial pressures, rather than evil intent, in large part explain the paucity of educational children's programming on commercial broadcast television stations. See Press Club Speech, supra note 220, at 7 ("II]t takes serious time, money, and commitment to program children's educational television. It's easier and more profitable to do almost anything else.").

243. See SUNSTEIN, supra note 9, at 85; Joint Comments of APTS/PBS, supra note 214 , at 9-19.

244. See Comments of the NAB, supra note 23, at 14-15; see also Statement of Rodney A. Smolla, supra note 46 , at 24-26.

245. Indeed, this is one of the few instances in which Professor Sunstein, Professor Powe, and Dean Krattenmaker share common ground. See KratTENMAKER \& POWE, supra note 9, at 81-84; SUNSTEIN, supra note 9, at 84-85. Moreover, Chairman Minow also endorses a regulatory response that relies on the strength of the public broadcasting system. See Minow \& LAMAY, supra note 2, at 157-61, 202-03.

246. The public broadcasting community has urged the Commission to take such action in the education children's programming docket. See Joint Comments of APTS/PBS, supra note 214 , at 9-19. 
Hundt's proposals represent a good faith attempt to improve the performance of commercial broadcasters. ${ }^{247}$ If nothing else, the mere existence of the rulemaking docket is likely to make commercial broadcasters more self-conscious about their programming selections. $^{248}$

However, there is little reason to beheve that the proposals, standing aloue, will significantly improve parents' program choices of free, over-the-air commercial television stations. Similar attempts to bring arouud reluctant broadcasters have failed, and the current proposals are unlikely to alter the Commission's track record.

Regardless of the merits of the particular proposals, they should be deemed constitutional. The First Amendinent claims of broadcasters have been vastly overstated, and both the academy and the Commission should examme the nature of these claims more closely. Incideut to this project, the Commissiou's legal authority to promote certain types of programming should be placed on firmer ground than the current Red Lion scarcity rationale. Contimued sole rehance on Red Lion is virtually certain to lead to a significant reduction in the Commission's powers to regulate broadcasters.

The Commission should also consider its ability to encourage partnerships between commercial and public broadcasters as an alternative to a command and control regime. If commercial television broadcasters are willing to voluntarily provide significaut financial and technical support to the public television system's efforts to educate children, the Commission probably should permit commercial television broadcasters to continue bundling aud selling mass audiences without significant new regulatory burdens.

Chairman Hundt has gone into the dense woods of the children's programming debate, and has dragged the commercial broadcasters with him. Although the odds of ultimate success seem

247. See generally Fiss, supra note 16, at 788 ("The state must put on the agenda issues that are systemically ignored and slighted and allow us to hear voices and viewpoints that would otherwise be silenced or muffled .....").

248. This effect may be the most significant result of Chairman Hundt's efforts. If broadcasters improve their efforts voluntarily in response to the specter of command and control government regulatiou, then the Chairman will lave achieved his policy objectives. At the risk of being cynical, the Chairman's main goal in championing this cause through the use of the Commission's rulemaking apparatus may well be to effect cliange through a "velvet" revolution. 
rather low, his initiative raises a critically important issue and has inspired spirited public debate. The nation is the better for it; our children are the better for it. $\mathrm{He}$ is to be congratulated for his efforts to ensure that there is something for children to watch on commercial broadcast television stations that is actually worth watching.

So, into the woods we must go, broadcasters, bureaucrats, and the concerned public. The cause is a worthy one; the game worth the candle:

Careful the things you say, children will listen. Careful the things you do, childreu will see.

And learn.

Clildren may not obey, but children will listen. Children will look to you for which way to turn,

To learn what to be.

...

Careful the tale you tell.

That is the spell.

Children will listen. ${ }^{249}$

249. Children Will Listen, in SONDHEIM, supra note 1, at 16. 